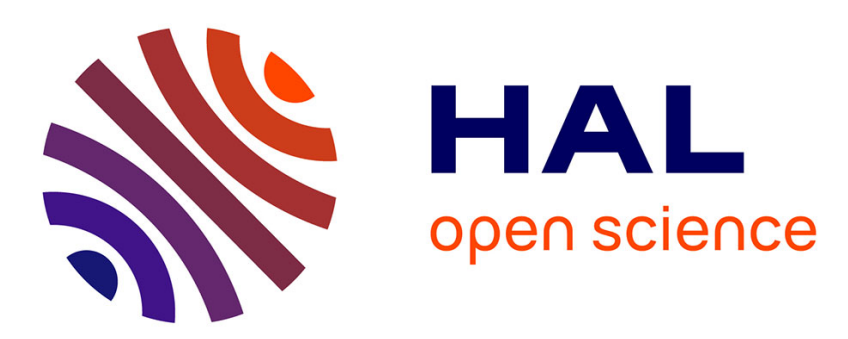

\title{
To march in phalanx, to jump with weights, to knead the bread, to tread the grapes. What is the aulos for?
}

Fábio Vergara Cerqueira

\section{To cite this version:}

Fábio Vergara Cerqueira. To march in phalanx, to jump with weights, to knead the bread, to tread the grapes. What is the aulos for?. Archimède: archéologie et histoire ancienne, 2016, 3, pp.187-205. hal-01587267

\section{HAL Id: hal-01587267 \\ https://hal.science/hal-01587267}

Submitted on 13 Sep 2017

HAL is a multi-disciplinary open access archive for the deposit and dissemination of scientific research documents, whether they are published or not. The documents may come from teaching and research institutions in France or abroad, or from public or private research centers.
L'archive ouverte pluridisciplinaire HAL, est destinée au dépôt et à la diffusion de documents scientifiques de niveau recherche, publiés ou non, émanant des établissements d'enseignement et de recherche français ou étrangers, des laboratoires publics ou privés. 


\section{ARCHIMĖDE}

ARCHÉOLOGIE ET HISTOIRE ANCIENNE

\section{DOSSIER THÉMATIQUE : DES FOSSÉS ET DES REMPARTS. ENCEINTES ET SITES FORTIFIÉS DU RHIN SUPÉRIEUR ENTRE PROTOHISTOIRE ET MOYEN ÂGE}

\section{Olivier BUCHSENSCHUTZ}

Avant-propos. Des enceintes en terre anhistoriques à Google Earth

8 Lizzie SCHOLTUS

Histoire de la recherche dans le bassin de Saint-Dié-des-Vosges

20 Maxime WALTER

Les sites de hauteur du massif vosgien. Actualisation des données et modalités d'implantation

37 Jean-Jacques SCHWIEN

Chateaux et enceintes des Vosges du Nord. Topographie et longue durée

49 Anne-Marie ADAM

La palissade dans tous ses états : I'enclos du Britzgyberg (Illfurth, Haut-Rhin) et autres aménagements palissadés dans les habitats du premier âge du Fer

60 Clément FÉLIU

L'enceinte inférieure du Frankenbourg (67) et les remparts à poteaux frontaux de la fin de l'âge du Fer dans l'espace du Rhin supérieur. Pour une révision de la typologie des Pfostenschlitzmauern

74 Jacky $\mathrm{KOCH}$ et Thomas FISCHBACH

Enceintes de hauteur en pierres et formes « primitives » de châteaux ? L'exemple du Bernstein

87 Adrien VUILLEMIN

Les enceintes urbaines en moyenne Alsace (1200-1850)

102 Jean-François PININGRE

Les enceintes de l'âge du Bronze et du premier âge du Fer en Franche-Comté. Un bilan des recherches

124 Clément FÉLIU et Jean-Jacques SCHWIEN

Conclusion. Nouvelles perspectives sur les enceintes du Rhin supérieur

\section{ACTUALITÉ DE LA RECHERCHE : ARCHÉOLOGIE DES RÉSEAUX}

\section{Claire CAMBERLEIN}

Les réseaux en archéologie : approche historiographique et interdisciplinaire

135 Thomas HUTIN

Lieux d'échanges et espaces publics en Gaule à La Tène finale

150 Streeve GENTNER

Économie du fer et voies de communication, de l'abattage du minerai à la distribution

du métal : I'exemple du nord de la Forêt-Noire au Ve siècle av. J.-C.

169 Loup BERNARD et Rémy WASSONG

Du Danemark au Fossé rhénan. Un siècle d'analyse des voies de communications protohistoriques : évolution des méthodes et mise en commun des données

184 Steeve GENTNER et Rémy WASSONG

Conclusion. L'archéologie des réseaux : une thématique aux multiples facettes

187 Fábio VERGARA CERQUEIRA

To march in phalanx, to jump with weights, to tread the grapes, to knead the bread. What is the aulos for?

206 Hermann AMON

Les supra-commandements comme solution à la crise militaire du III siècle de l'Empire romain sous Philippe l'Arabe et Gallien

218 Martina BONO

Il processo di Cremuzio Cordo in Dio LVII, 24, 2-4

\section{LA CHRONIQUE D'ARCHIMÈDE}

228 Frédéric COLIN (éd.)

La Chronique d'Archimède. Bilan des activités scientifiques 2015-2016 de I'unité mixte de recherche 7044 


\title{
VARIA
}

\author{
dir. Maria Teresa Schettino et Yannick Muller
}

\author{
TO MARCH IN PHALANX, TO JUMP WITH WEIGHTS, \\ TO KNEAD THE BREAD, TO TREAD THE GRAPES. \\ WHAT IS THE AULOS FOR? [1]
}

RÉSUMÉ cal des activités physiques que sont, par exemple, le travail, les pratiques athlétiques ou militaires. Ces accompagnements, principalement exécutés au moyen de l'aulos, sont attestés dans les documents iconographiques et textuels, sur un millénaire environ, depuis les poèmes homériques jusqu'aux textes et aux mosaïques de l'époque de Justinien. Cette étude tente d'identifier une logique propre à ces phénomènes culturels : il s'agit de déterminer si les raisons des différents usages musicaux dans des activités aussi diverses que sont l'agriculture, les pratiques athlétiques et militaires suivent une même logique générale sur le temps long, sur le mode d'un facteur transhistorique, ou si cette similarité n'est que superficielle. Une étude du corpus des œuvres méliques et, parallèlement, des représentations iconographiques des scènes de vendanges (foulage du raisin) et de pétrissage du pain. Une étude des textes antiques élaborant diverses explications

\section{KeYwords}

Grèce ancienne, musique,

aulos,

instruments de musique, archéologie de la musique, poésie mélique,

iconographie,

guerre,

athlétisme. époque romaine impériale,

\author{
Fábio VERGARA CERQUEIRA \\ Professor de História Antiga \\ Universidade Federal de Pelotas \\ Gastwissenschaftler - Universität Heidelberg
}

fabiovergara@uol.com.br
The present article aims to study the musical accompaniment of physical activities such as work, athletic or military practices. Such accompaniment, mainly by the aulos, is verified over a millennium both in iconographic and literary sources from the Homeric poems to late Antique texts and mosaics from the time of Justinian. This work seeks to identify an internal logic of this cultural phenomenon and to investigate whether the reasons for this musical usage over this long period, in varied situations, including labour, athletic and military activities, follows the same general trans-historical logic, or whether the likeness is only superficial. Therefore, it analyses the musical repertoire of work songs, and the related iconography of the vintage or bread-kneading. Furthermore, it looks for the cultural explanations formulated in Antiquity for the presence of aulos-music in sporting competition and military activities. It concludes that on the level of rhythm and melody there was a form of permanence regarding the internal logic. de mettre en évidence que, sur plan du rythme et de la mélodie, i y a une forme de permanence de cette logique. cette analyse. Il est alors possib
Mots-CLÉs Ancient Greece, Roman Empire, music,

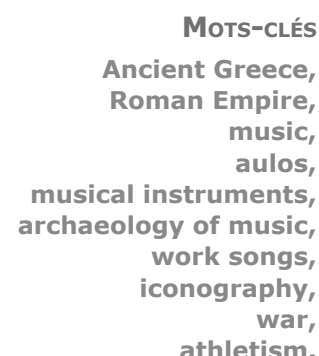

athletism. 
First and foremost, I would like to express my gratefulness to the scholars and colleagues who, in different manners and moments, contributed to the elaboration of the present paper: to Reinhard Stupperich and Ennio Sanzi, for general advices; to Maria Aparecida de Oliveiera Silva, for the cooperation in translation of Greek texts; to Priscilla Ferreira Ulguim and Andreas Zanker, for the careful revision of my English version of the paper; to Cristiano Gehrke, for his assistance on the images; to Jean-Pierre Brun, for franchising his personal library in Naples, particularly devoted to wine production in Antiquity; and finally to Zdravko Blažekovic, for the stimulus to publish the paper. I also would like to thanks the institutions that gave me conditions for the development of this research, in particular the Department of History of the Federal University of Pelotas, Brazil, the Institute of Classical Archaeology of Heidelberg University, Germany, and the Centre Jean Bérard / École française de Rome, in Naples, Italy, with attentive welcome by the director, Claude Pouzadoux. This work is made possible by the financial support of Humboldt-Foundation Fellowship as "Experienced Researcher" on Classical Archaeology and of the Productivity Fellowship on Historical Archaeology of Brazilian Council for Scientific Research - PQ-2/CNPQ. Nevertheless, the concepts and arguments exposed and articulated in this paper, as well as eventual misunderstandings, are responsibility strictly of its author.

\section{THE AULOS-ACCOMPANIMENT OF WORKING ACTIVITIES.}

We have inherited a group of figured monuments from antiquity that represent a common practice in the world of work: working songs, i.e. the musical accompaniment of working activities, played mostly, but not exclusively, by the aulos. These monuments are found spread throughout a wide area in the Mediterranean, with dates covering a period of more than ten centuries. Among the most ancient iconographical testimonies we may set two monuments from the sixth century B.C., one from Boeotia and the other from Athens: a terracotta piece, conserved in the Louvre Museum, and a black-figure amphora by the Amasis Painter, conserved in the Würzburg Museum. The first of these displays is an auletês accompanying four women involved in the rolling of bread (fig. 1); the second shows a satyr blowing an aulos, while another one treads grapes in order to produce wine (fig. 2). Grape-treading accompanied by the aulos has provided a significant quantity of visual representations, stretching as far back as the sixth century B.C., as evidenced by the mosaic from Mount Nebo, Jordan, the mosaic from Beisan, ancient Scythopolis, in Israel, from the Monastery of Lady Mary, and the mosaic from the Saint Christopher Church, in Kabr Hiram, Lebanon, conserved in the Louvre Museum (fig. 3).

[1] The present text corresponds to the paper presented, as invited speaker, at the $14^{\text {th }}$ FIEC Conference - Fédération Internationale des Associations des Études Classiques, at Bordeaux (France), entitled "Fouler le raisin, pétrir le pain, sauter avec des haltères, marcher en phalange. Enfin, à quoi ça sert l'aulos ?", as opening lecture of the Panel 3 (NVMERI INNVMERI "numberless numbers": music and meter in the Classical World), on the $28^{\text {th }}$ August 2014.

[2] The phorminx is the term mostly used in Homer to identify
The Homeric description of the "Shield of Achilles" comprises the earliest testimony regarding the musical accompaniment to the gathering of the vintage. The Homeric narrator notes that, during the harvest of the grapes, in the midst of boys and girls carrying bunches of grapes in woven baskets, a boy gracefully sings the "song of Linos" in a voice that sounds like an aulos, accompanied by his "clear-sounding" phorminx [2]. The other boys and girls follow him and, by stamping their feet in unison, they make small leaps, while dancing and shouting with joy [3]. An epigram by Agathias Scholasticus (AD 536 - 582), who was active in the Justinian court, and therefore contemporary to the abovementioned Jordanian, Lebanese and Israeli mosaics, can be counted among the final literary testimonies from the period of Antiquity. In alluding to the use of the aulos in the vineyards, Agathias mentions a song that supports the peasants' work - one with a Bacchic, vibrant and joyful rhythm [4]. This epigram leads us to the metaphorical connection between wine (including the religious and social consequences of its consumption) and the Dionysian and satiric ambience, present from very early Greek literary and iconographical sources onwards, thus reiterating the approach found on the Würzburg amphora by the Amasis Painter that had been produced a thousand years earlier. Thereby, the tradition of visual representations of the epilênion aulêma accompanying the treading of the grapes oscillates

the ancient form of cithara known in early archaic times. It was not the precedent form of the classical kithara, known as Asia, which evolved from a variation developed in Eastern Greece, nor corresponded to the lyra with the tortoise-shell sound box, known as chelus. It probably evolved into the classical "cradle-cithara" with a rounded bottom.

[3] Homer, Iliad, XVIII, 566-571.

[4] Agathias Scholasticus in Anthologia Palatina, XI, 64. 


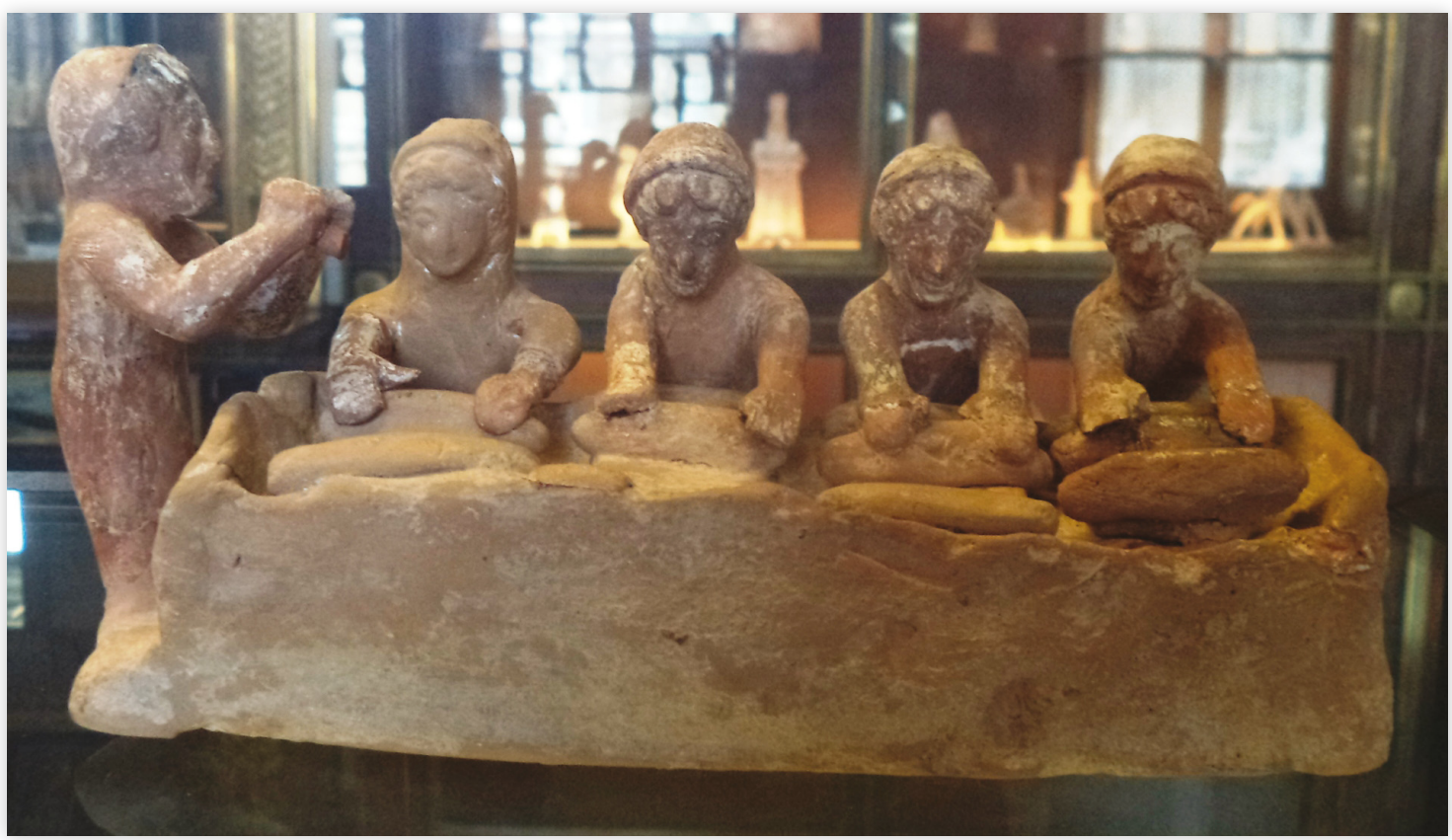

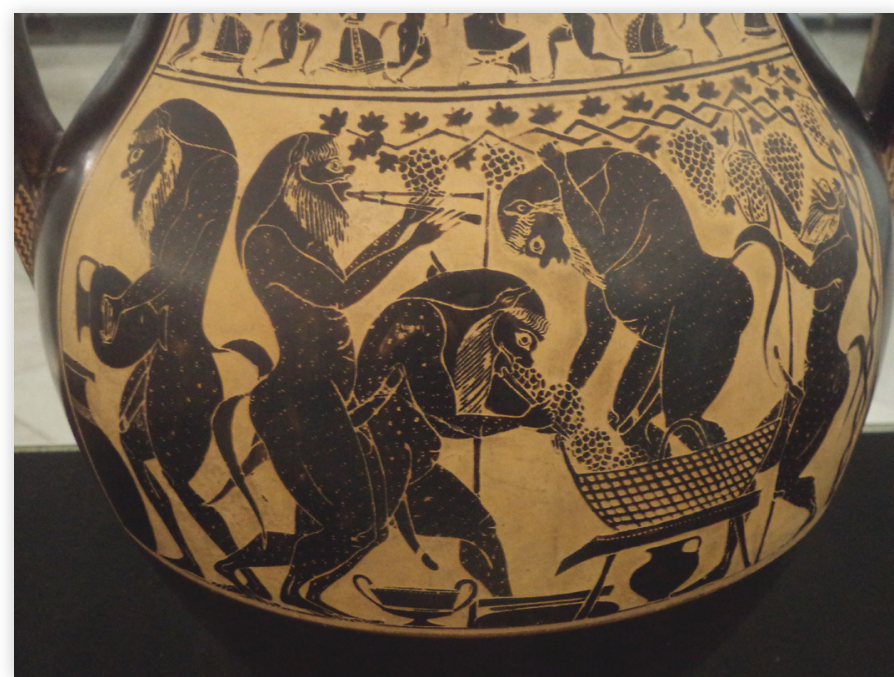

between idealization and realism, between human and mythological representations, as well as between satyrs and amorini [5], as we can verify in the famous "Vaso Blu", dated from AD 25-50, from Pompeii (fig. 4), in a Campanian terracotta from the second half of the first century, conserved in Würzburg (fig. 5), and in a GalloRoman mosaic from Saint-Roman-en-Gal, produced in Vienne in the early third century (fig. 6).

The repertoire of working songs has been already well studied in a systematic manner by Gérard LAMBIN (1996), Annie BÉLIS (1999) and Eleonora Rocconi (2010) [6],

[5] Erotes depicted as children or babies, whose variants are known as amorini, Cupids or putti, are already present in early Hellenistic art, such as in Apulian Gnathia vases from the late fourth century and early third century B.C. "The combination of Silenus, the Dionysiac figures, and the vines with vintaging Erotes and putti, alludes to the influence of Dionysus and the power of wine, rather than specific ceremonies involving the wine god". ECKERSLEY 1995, p. 96.

[6] LAMBin 1999. RocConi 2010.

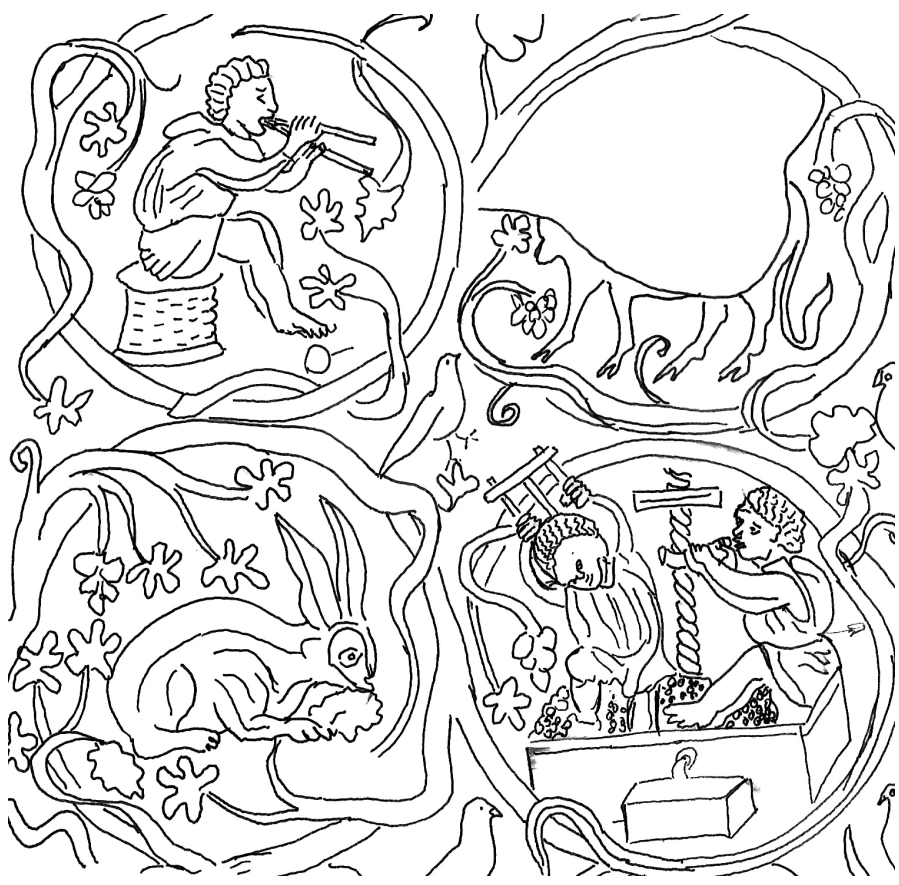

A Figure 3 : different scenes related to the vintage. The combination of two scenes shows the aulos player accompanying the grape-treading. Mosaic. c. AD 575. Proto-Byzantin, from Saint Christoph Church, in Kabr Hiram, near to ancient Tyre, Lebanon. Paris, Louvre Museum, MA2231. Drawing: F.V. Cerqueira.

enabling the establishment of a list of such songs and the definition of some of their musical features. First of all, these are popular songs, whose performance takes place within a quotidian setting. Hence, they are less well-known than the type of music that was appreciated within official and erudite circles - that of festivals, theatre and musical contests, present in theoretical as well as practical musical instruction. This more erudite musical stratum aroused greater interest among the ancient authors, and is therefore well represented 

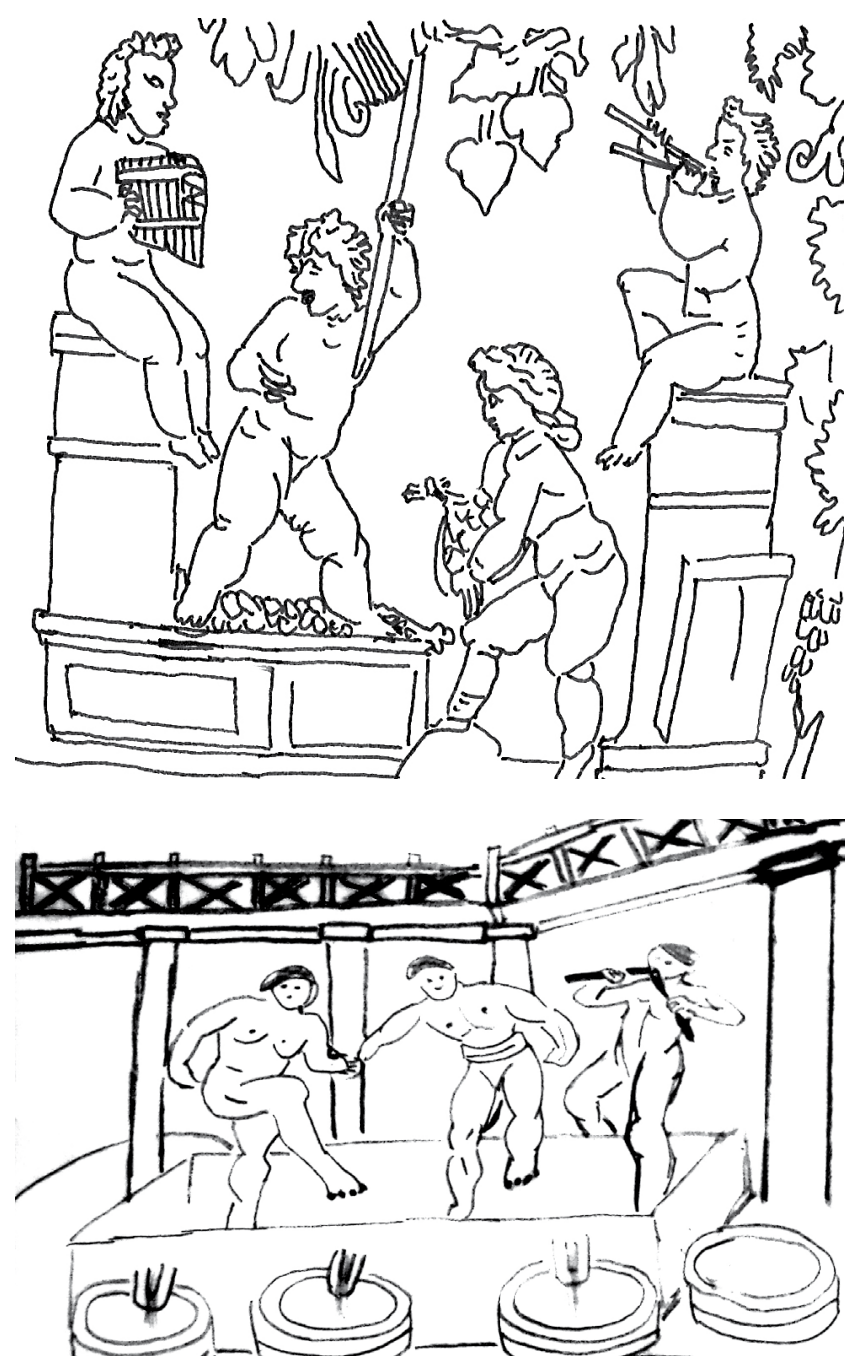

in the classical literary tradition. It was even subjected to Pythagorean and Aristotelian theoretical, acoustic and moral reflections. On the other hand, the set of popular songs to which the working songs belonged, drew much less intellectual attention and is therefore less known. Livio Sbardella considers that the description of the "Shield of Achilles" had already established the contraposition between the erudite circle, to which the aoidos belonged, and, on the other hand, a popular circle, to which the peasant song tradition belonged, alluded to by the abovementioned Homeric quotation about the "boy who sings with a voice that sounds like an aulos" [7].

Furthermore, among the popular songs, which include different forms and genres, it is the love songs that are best known. Unlike these, the work songs belong to one of the lesser-known forms, which is why we owe so much to iconographical testimonies [8]. In order to establish

[7] SBARDELLA 2009, p. 65-66.

[8] RocConi 2010, p. 26-27.

[9] Athenaeus, XIV, 618d-619c; Pollux, IV, 53-56.

[10] Rocconi 2010.
$<$ Figure 4

Vintage scene with four amorini, two of them involved in the grape-treading, and two playing musical instruments (aulos and syrinx). "Vaso Blu", cameo-glass. Pompeii. AD 25-50. Naples, Museo Archeologico Nazionale, 13521. Drawing: F.V. Cerqueira

$\checkmark$ Figure 5

A Dionysiac scene depicting a vintage: a satyr plays the Phrygian aulos, accompanying two satyrs treading the grapes, while a third one turns out grapes over the treading structure. Terracotta antefix. AD 50-100. Würzburg, Martin von Wagner Museum, H2678. Photo: F.V. Cerqueira.

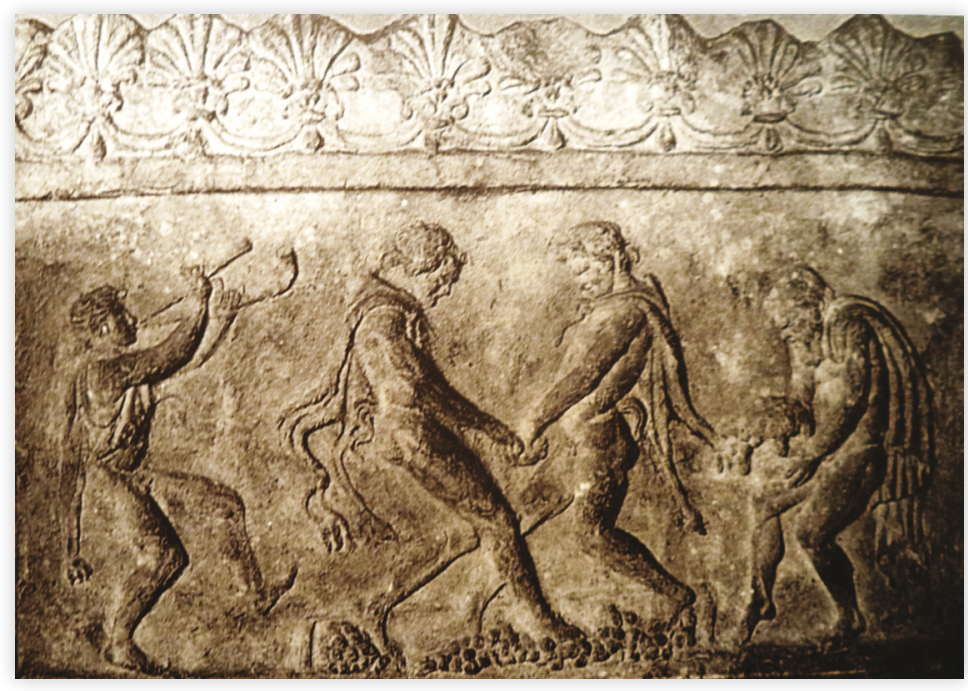

< Figure 6 : two man working in the grape-treading, accompanied by an aulos player. Gallo-Roman mosaic. Provenance: SaintRomain-en-Gal (Rhône River). Produced in Vienne. Early III century AD. Musée Archéologique National de SaintGermain-en-Laye, inv. 83116. Drawing: F.V. Cerqueira

a general view of the repertoire of ancient work songs, we depend to a great degree on two imperial sources: Athenaeus of Naucratis and Julius Pollux [9]. I follow here the most complete repertoire, even if synthetic, as defined by E. RocConi [10]:

a. litierse [11]. The "reaper's song". Of Phrygian origin, it corresponded to the Borimos, sung by the Mariandinos peasants, and to the manerôs, which was sung among the Egyptians. [12]

b. bôrmo or bôrimos [13]. A song employed to accompany agrarian works. Of funerary origin, it was a "threnodic song for the rural tasks". Rocconi points out that the same name, Borimos, was given to a certain type of aulos, also known as Mariandunoi kalamoi, which would have accompanied rural activities.

c. oulos / ioulos [14]. The "harvest song" and the "shearing song".

[11] Athenaeus, XIV, 619a.

[12] Pollux, IV, 54. Cf. Athenaeus, XIV, $619 f$.

[13] Pollux, IV, 54sq.

[14] Athenaeus, XIV, 618d-e. 
- As the "harvest song", its form corresponds to a hymn to Demeter also named as Oulo or Ioulo [15], the "goddess of the bales" [16]. Thereupon, these songs were also known as dêmêtrouloi or kalliouloi, "Demeter bales" or "beautiful bales".

- As the shearing song, it was the "song of one who works the wool" [17].

d. ptistikon or ptismon (sc. aulêma or melos) [18]. The milling song, accompanied by the aulos.

e. linos or ailinos [19]. The "song of the vintage". A funerary lament in memory of Linos, son of Apollo, sung not only on mourning occasions, but also at joyful moments [20], as suggested by the ambience of the vintage described in the "Shield of Achilles", as well as in various iconographical representations, in which the presence of the satyrs, and even amorini in the imperial period, creates a cheerful atmosphere, appropriate to the Dionysian symbolism of this activity.

f. alêtis [21]. "The vintage song". Originally linked to the "swing party" in honor of Erigone, called Aiora, it was celebrated in Athens during the vintage period, hence associating them with one another.

g. epilênion aulêma [22], or melos [23], or humnos [24], or orchêsis. "The presser song", accompanied by the aulos, during grape-treading. It derives from lênos, a kind of press for treading the vine. In Daphnis and


consisted of an غ̇ंı syrinx [25].

h. himaion asma. The "song for drawing the water from the well" and the "miller song".

- The "song of he or she who pulls the rope (of the well)".

[15] Pollux, I, 38; cfr. Athenaeus, XIV, 619b.

[16] Didymi, in: SCHMIDT \& MoRITz 1964, Chalcenteri grammatici Alexandrini fragmenta quae supersunt omnia, Amsterdam, $2^{\text {nd }}$ ed. [ $\left.\left.1^{\text {st }} 1854\right]\right)$, p. 66.

[17] Athenaeus, XIV, 618d.

[18] Pollux, IV, 55.

[19] Homer, Iliad, XVIII, 561-572.

[20] Athenaeus, XIV, 619c.

[21] Athenaeus, XIV, 618e. Cfr. Pollux, IV, 55.

[22] Pollux, IV, 55.

[23] Callixenos of Rodhes, FGrHist $627 \mathrm{~F} 2$.

[24] Carmina Anacreontea, 59, 7-8 (ed. West).

[25] Longus II, 36, 1.

[26] Scholia on Aristophanes, Frogs, 1297a.

[27] Callimachus, fr. 260, 66 (ed. Pfeiffer).

[28] Ap. Athenaeus, XIV, 618d.

[29] Athenaeus, III, 109.

[30] Aelianus, Varia Historia, VII, 4; Plutarch, Septem sapientium convivium, XIV, 157d-e.

[31] Pollux, IV, 53.

[32] Rocconi 2010, p. 28. Eratosthenes, fr. 10, in: Johannes U. Powell, Collectanea Alexandrina (Oxford: Clarendon Press,


and therefore to the act of drawing water from the well, pulling the water bucket, either running through pulley or just holding the rope by hand [27].


related to the Imalís (literally, "from abundance"), provides a link to the plentifulness of flour, a reminder that Demeter was known by the epithet of "Abundant" in Syracuse [29]. We also find the meaning of "millstone song" [30] and "millstone singer", the himaoidos [31].

Rocconi associates a fragmentary testimony by Eratosthenes of Cyrene to wool working [32]. However, in my view the fragment actually connects the ioulos with the production of dough, a task that, even though a type of manufacturing, is linked through its raw material to Demeter [33]. Thus, the interpretation of this evidence relates to the theme of the Boeotian terracotta from the Louvre cited at the beginning of this paper (fig. 1).

The music of the aulos accompanied terrestrial cargo, as well as maritime transport. Thanks to Sextus Empiricus' testimony, we know that the aulos and the salpinx accompanied the transportation of heavy loads [34]. The role of musicians in navigation is significant for understanding the "working songs". The waters of the Mediterranean were crossed by variety of ships, accompanied by the music of the aulêtai, who played the eretikon, the "rowers' song", to provide the correct rhythm for the movement of the oars [35]. Known in Athens as the trieraulês [36], the aulos-player on a trireme was often a foreigner, a free employee, such as the aulêtês specified in a list of the crew of an Athenian trireme, the piper Sogenes of Siphnos [37]. However, this was generally considered

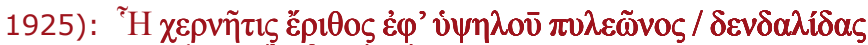


Eleonora Rocconi: "là, dove la salariata operaia, nell'alto vestibolo, focacce d'orzo stava preparando e belli iuli canta."

[33] Translation into Portuguese of Eratosthenes, fr. 10, by Maria Aparecida de Oliveira Silva: "A trabalhadora, no alto vestíbulo, preparando um bolo de cevada, canta belos hinos a Demeter (iouloi)." (English version of Portuguese translation, by the author: "The maid, in the upper chamber, preparing a barley cake, sings beautiful hymns to Demeter (iouloi)". The direct connection between the preparation of cake and the hymns to Demeter leads to the context of bread-kneading accompanied by the aulos music depicted in the Boeotian terracotta.

[34] Sextus Empiricus, Against the Musicians, 18.

[35] Pollux, IV, 56; Plutarch, Alcibiades, 32.

[36] On the denomination, see Pollux, I, 96.

[37] "List of crew of Athenian triremes" (or "Naval catalogue inscription"), IG i3 1032, col. 7, I. 162 (=IG II/III2 1951).

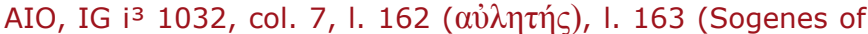
Siphnos); col. 8, I. 298 (piper?), I. 299 (-nes of Pri[ene?]). https://www.atticinscriptions.com/inscription/IGI3/1032 (trans. by Stephen Lambert and Robin Osborne). The translators observe, in note 8 , that the pipers on this inscription are consistently foreign. On this inscription see: GraHAM 1992, p. 257-70; LAING 1965. 
a less prestigious function, performed by aulêtai of low social extraction, for example individuals of servile origin, such as the supposed lover of Aeschines mother, named Phormion, who was a slave of Dion de Phrearres [38]. Amid the oars' creaking and the waves' breaking on the ship's hull, the continuous and penetrating sound of the aulos guaranteed the maintenance of a regular rhythm, according to the speed defined by the keleustês, the chief rower [39]. We owe to Longus a very enlightening excerpt about the musical accompaniment of the rowers, who sang sailors songs with the aim of distracting themselves from fatigue [40].

Based on the selection of testimonies listed by Rocconi, augmented by the other registers enumerated above, we have an outline of the repertoire of working songs that points to the use of music, mostly songs accompanied by aulos, in a series of production chains, suggesting that they were aligned according to an economical logic:

1. General agrarian production:

a. Song that accompanied farming activities: bôrmo or bôrimos, using the aulos called Mariandunoi kalamoi.

2. Wine productive chain (grapes harvest and treading):

a. Vintage: linos/ailinos ("song of Linos"), alêtis ("swing song").

b. Grape-treading: epilênion aulêma/melos/humnos/ orchêsis ("pressing song", or "tread-song").

3. Production chain for cereal grains, including the corn, flour and bread (harvest, milling and baking):

a. Reaping: litierse ("reaper's song"), oulos / ioulos ("harvest song"), or also dêmêtrouloi ("song of Demeter bales") or kalliouloi ("song of beautiful bales").

b. Milling: ptistikon or ptismon ("milling song"), himaios ôdê ("song to mill", or "millstone song").

c. Bread kneading/beating: ioulos ("bread kneading song").

4. Wool production chain (shearing and weaving):

a. Shearing: oulos / ioulos ("song of one who works the wool").

5. Water supply (drawing water from the well):

a. Himaion asma ("Song of one who pulls the rope").

6. Goods transportation (navigation and cargo transport):

[38] Demosthenes, On the Crown, 129.

[39] BÉLIS 1999, p. 76-77.

[40] At the same time, the passage Longus III, 21, 2, reveals one aspect that, according to Rocconi, would be one of the main musical features of the working songs, the responsory: "et ce que font tous les marins pour ne pas sentir la fatigue, a. Eretikon ("rower song", performed by the so-named trieraulês).

b. "Song of the weight porter".

The use of the aulos-accompaniment in work songs is present in most of these activities, as demonstrated above. Literary and epigraphic testimonies suggest its usage in the "rower song", while literary sources indicate that it accompanied goods being transported through the city. Milling was accompanied by the tune of the aulos, as indicated by the musical category aulêma that identifies the ptistikon aulêma [41]. In addition, according to Boeotian terracotta iconography, the pipes could accompany the "bread kneading song". They also regularly accompanied songs performed during general farming activities, in particular the "reaper's song", when variations of this musical instrument named as Bôrimos or Mariandunoi kalamoi were employed. Last, but not least, the presence of the aulos during grape-treading is verified through iconographic and literary sources, accompanying the "presser song" (the epilênion), also classified as an aulêma.

In opposition to the evidence cited above, some sources indicate the usage of other instruments. The "song of Linos" described by the Homeric narrator, was sung during the grape harvest and accompanied by a stringed instrument. It is necessary to point out, however, that this archaic reference is the only quotation known to the author of a stringed instrument appearing during the vintage. This indicates that the aulosaccompaniment was not usual in Homeric times, which appears probable, as the pipes are rarely mentioned in the Iliad and the Odyssey. Nevertheless, one of the few passages in Homer where this instrument is noted is precisely during the description of the voice of the boy who sang the "song of Linos", which sounded like an aulos. What does this mean? I do not want to enter the long discussion about the layers of temporality in the "Shield of Achilles", but the quotation of the aulos may likely refer to the influence of a later period in the Homeric text. However, I could infer that the sonorous quality of the aulos, later associated with the threnodic êthos, was already considered an appropriate accompaniment to agrarian activities, which shared imaginary funerary symbolism.

On the other hand, Longus refers to the possibility of accompanying the epilênion with the syrinx, the

ils le faisaient eux aussi en soulevant leurs rames : le chef des rameurs chantait, seul, des chansons de marins, et les autres, tous en chœur, reprenaient à leur tour d'une seule voix ce qu'il venait de chanter." (trans. Aline Tallet-Bonvalot)

[41] The term aulêma identified a genre of chant, which was sung with the aulos-accompaniment. 
musical attribute of the god Pan which was linked to the pastoral world [42]. The presence of Pan or of his musical instrument in Dionysian scenes is frequent in Apulian vase-painting from the fourth century B.C. until the art of Imperial times, as one can see in the "Vaso Blu" from Naples (fig. 4). Furthermore, this should not cause surprise, for the syrinx was familiar to peasants. According to Aristoxenus, writing in the late fourth century B.C., they learned to play both the aulos and the syrinx without specific classes [43]. Thus we conclude that the aulos, despite prevailing in the accompaniment of work songs, was not the only instrument used in such situations, because on certain occasions the syrinx was acceptable.

Considering the common trait of physical activity based on repetitive movements, the iconographical repertoires, when cross-checked with the ancient texts, point to two analogous modalities of musical accompaniment, mainly by the aulos. These take place during athletic and military activities. Regardless of their dispersal over more than a thousand years and several regions of the ancient Mediterranean, the iconographical and literary evidence for auletic accompaniment belong to the same "category of thought", insofar as they are permeated by a "trans-historical constant" [44]. It is in this perspective, in considering them as analogous "facts", even though distant and separated in time and space, that I propose to consider them in synchrony, classifying them in the same category, supposing they are comprehensible through the same trans-historical constant.

This trans-historicity lies in the internal logic of this cultural system, characterized by the musical accompaniment of various repetitive physical activities labour, sporting or military. Hence, in understanding their belonging to the same category of "facts", as "twin facts", we may take advantage of the musical accompaniment of military, sporting and working activities

[42] Pan himself created his own musical instrument, the socalled Pan-flute, known in Antiquity as the syrinx. He used the reeds into which Syrinx, his beloved nymph, had turned, after dying, throwing herself over the reeds in an attempt to escape to Pan's harassment. He picked up seven reeds, cut them, obtaining seven tubes, attaching one to another with beeswax, which was also used to fill each tube to different levels, in order to perform melodies employing the seven tones of scale. The instrument symbolized the suffering of love, but it also had mystic powers, which justified its usage in pastoral rituals. Pan fell in love with Daphnis, teaching him to play the syrinx, so that he became the first mortal to play this instrument. Homeric Hymn. Hymn 19 to Pan, 14-26. Euripides, Electra, 699sq; Ion, 492sq. Plutarch, Moralia, 1113b. Longus, II, 31 .

[43] Athenaeus, IV, 174e-f.

[44] Accordingly to VEYNE 1976, these facts comprise "almost identical twins". Our goal here is to scrutinise the underlying together in our interpretation. That is why the following sections of this study will review the descriptions and explanations given by ancient authors for the aulosaccompaniment of military and athletic activities, since it may also help us to understand the deep reasons for this practice during work activities, such as wine-making. Three questions should remain on the horizon during the analysis: 1) Does the presence of music accompanied by the aulos follow one and the same general logic for all activities? 2) Or, on the contrary, does the presence of music with such various activities follow a particular logic in each case, inherent to the uniqueness of each spatial-temporal context? 3) Or, might there be two different levels of impregnation of the internal logic: a general level, of trans-historical character, and a particular level, belonging to the singularity of each event and phenomenon?

\section{THE AULOS-ACCOMPANIMENT IN ATHLETIC ACTIVITIES}

Athenaeus explains that the Greeks exercised with musical accompaniment, as it helped them to regulate their movements [45]. The aulos was chosen to maintain the correct rhythm of movement in athletic games, aside from races, in which the salpinx was used. Archaeological finds endorse this observation. The island of Delos, where a significant number of fragments identifiable as ancient auloi sections have been found [46], has revealed five examples of auloi associated with the palaestra [47]. Ancient texts contain many examples from the Peloponnese, while the iconography reveals abundant Attic material concerning the daily life of the Athenian palaestrae, school contests and public festivities (fig. 7 - 8). Plutarch speaks of the musical accompaniment by the aulos during the Sthenia in Argos [48], whilst

reasons for the longevity of this custom. Here we benefit from an anthropological perspective, with a synchronic look at the vestiges that are distant from one another in a diachronic and geographical scale, attempting to understand the internal logic of this cultural system.

[45] Athenaeus, XIV, 629. Regarding practical aspects of athletic modalities, one should highlight that iconographical evidence is much richer, more varied and enlightening than the scattered information brought by ancient texts, whereas literary evidence, mainly from imperial period, provides us with clues about the cultural meanings of this custom.

[46] BÉLIS 1998, p. 777-790.

[47] B 5137 (Palaestra N or Palaestra of the Lake); B 5384 e 5388 (house in the east of the stadium); B 5150 (near the Palaestra); e B 4452 (Large Palaestra, or Granite Palaestra). Cf. DÉONNA 1938, p. 242-248, note 4, pl. LXXV-LXXVIII and 321-25, pl. XCII. 




A Figure 7

A young leaper, naked, with halters in the hands, preparing to jump, accompanied by a professional aulos player, as indicates the phorbeia and khiton poderes he wears. Attic red-figure pelike by the Polygnotos Group (ARV² 1060/135). c. 440 B.C. London,

British Museum, E 427. (C) Trustees of the British Museum.

Athenaeus notes the same regarding the Gymnopaedia in Sparta [49].

The only testimony referring directly to the accompaniment of athletics by the aulos at Athens in the Classical period is a passage by Xenophon [50]. In the Hellenica, he reports on the athlete Thibron who, one morning in the year 391 B.C., went out to train discus throwing. He was accompanied by the aulêtês Thersander, who, besides being an excellent piper, was strong and used to fighting [51].

Given the solid musical tradition of the Argives, namely in auletics, having been regular champions in musical contests, mostly in the sixth century B.C., there was a

[48] Festival in honor of Danaos. Pseudo-Plutarch, De musica, XXVI, 1140c-d.

[49] Athenaeus, XV, 613b, 618c. LARMOUR 1999, p. 71 and 181.

[50] Xenophon, Hellenica, IV, 8, 18.

[51] LARMOUR 1999, p. 70.

[52] Herodotus, III, 131; Polybius, IV, 20, 4-21; Pausanias, VI, 14,$10 ; X, 7,4$.



A Figure 8

Two fighters boxing to the sound of the aulos, played by a professional musician, and assisted by the judge, who intercedes for them to stop the fighting. Attic black-figure amphora. Near to the Painter of Munich 1519. Group of Copenhagen 114 (ABV 395/3). 510-500 B.C. Munich, Antikensammlung, 1538 (J 578). Drawing: F.V. Cerqueira.

historical tradition, endorsed by Herodotus, Polybius and Pausanias [52], that attributed to Argos the introduction of the aulos in the palaestrae and athletic competitions [53]. These authors were probably influenced by the reports of the role of Sacadas of Argos and Pythokritus of Sicyon in the development of auletic performance oriented to support sporting activities. The aulêtês Pithokritus, six times consecutive winner in the Phutikos nomos at Delphi (575-554 B.C.), also played at the Olympic Games six times, accompanying the pentathlon [54].

The fact is that the practice spread, reaching different regions, regardless of what its origin actually was. Late authors state clearly that, in ancient Greece, one could not conceive of a palaestra or an athletic contest without the aulos, as indicated by Plutarch in Peri Mousikês

[53] On the reputation of Argive musicians in Antiquity, see: VANDENSTEENDAM 1988, p. 129.

[54] Pausanias reports that his reputation in Olympia earned him a statue in his honor (Pausanias, II, 14, 10). This case illustrates well how aulêtai, who were famous as soloist concert musicians, could act as well in an apparently secondary function, as the accompaniment of athletic games, for it should ensure them the maintenance of their professional visibility, besides a good earning. 


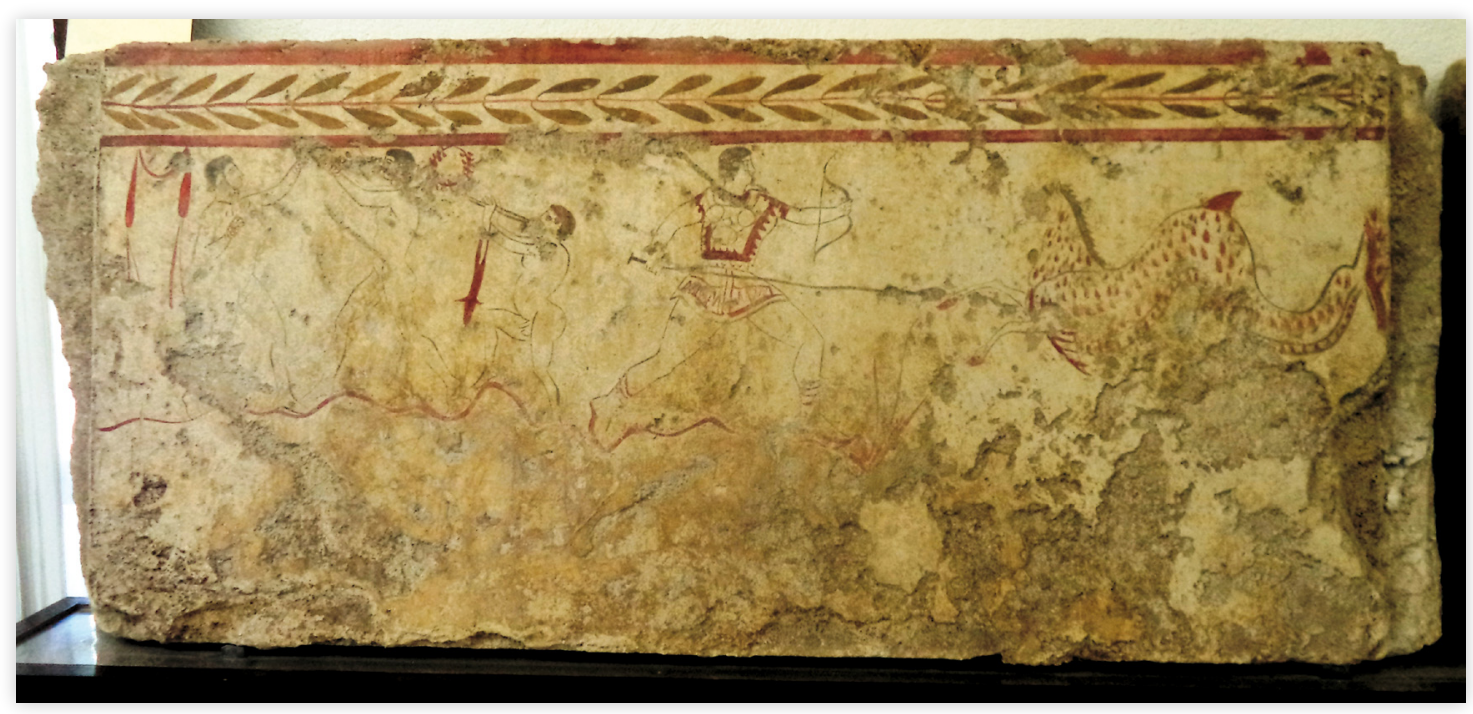

$<\vee$ Figure 9

Young aulos player, naked, with sybene suspending on his left arm, accompanies two boxers. Tomb painting. Paestum, Arcioni, Tomb I (1990). 370360 B.C. Paestum, Archaeological Museum. Photo: F.V. Cerqueira.

and endorsed by Pausanias [55]. Such usage spread across the Mediterranean regions under Greek influence. In Paestum, the tomb paintings represent aulêtai close to athletes who are boxing with each other [56]. (fig. 9 et 10) In Etruria, pugilism accompanied by aulos seems to have been popular, as evidenced by an Etruscan amphora from the beginning of fifth century B.C. (fig. 11) [57].

The aulêtai probably adapted traditional auletic repertoires to such athletic performances. In Olympia, for example, in accordance with a report of Pausanias, jumping contests in the pentathlon were accompanied by the Puthikon aulêma. Pausanias, Strabo and Pollux believed that it consisted of the same Puthikos nomos from Delphi, supposedly invented by Sacadas, imitating in music the fight between Apollo and the serpent Python [58]. In Peri Mousikês, Plutarch recalls a composition of Hierax, called Endrome, performed by aulêtai during the pentathlon [59]. According to David Larmour, the name suggests a connection with races [60]. During the Gymnopaedia, an aulêtês played songs composed by Thaletas of Crete and Sacadas of Argos [61].

[55] Pseudo-Plutarch, De musica, XXVI, 1140d; Pausanias, VI, 14, 18. Cfr. LARMOUR 1999, p. 69.

[56] Pontrandolfo, Rouveret \& Cipriani 1997, p. 45-47, fig. 44-45.

[57] The Uprooter Class (ABV 589/3). Berkeley, University of California, 8/445. Corpus Vasorum Antiquorum, University of California 1 (EUA 5) IV B, pl. 29.2.

[58] Pausanias, V, 7, 10; Strabo, IX, 421; Pollux, IV, 78.

[59] Pseudo-Plutarch, De musica, XXVI, 1140d.

[60] Its character may correspond to the "courante" movement of the French baroque suite.

[61] A significant part of this repertoire came from dance, given the common purpose of moving in accordance with rhythmic discipline. Cfr. LARMOUR 1999, p. 71.

[62] A catalogue of Attic black- and red-figure vases representing athletics accompanied by the aulos: Jumping with weights: Bearded piper 1) Belly-amphora. B.F. (ABV 384/16) Basle, Antikenmuseum, BS 06.294. CVA Basle 1,

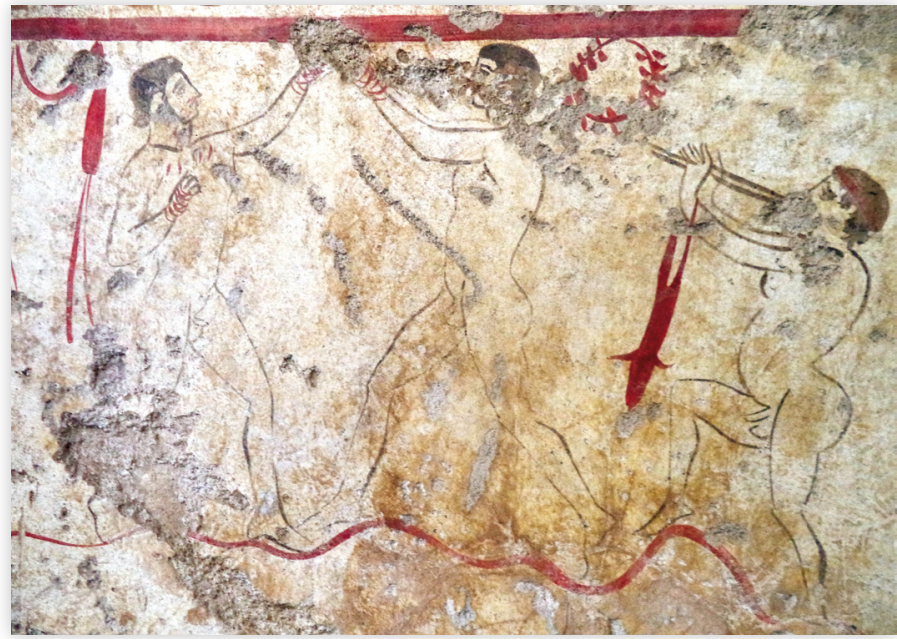

In some cases the written sources specify the athletic context, corroborating evidence from Attic pottery. Based on a comprehensive inventory of 56 black- and red-figure vases representing aulêtai accompanying athletic activities (in training or competitions), I conclude that these vase painters associate the performance of the aulos with all modalities of the pentathlon, and to a lesser degree, with wrestling, boxing and running [62].

pl. 42.6; 43.3. 2) Calyx-krater. B.F. (Para 149/23bis) Toledo, Toledo Museum of Art, 63.26. 520-10. CVA Toledo 1, pl. 1719. 3) Lêkythos. B.F. Pintor de Kephisophon. (ABV 669) New York, Metropolitan Museum of Art, 08.258.30. Unbearded piper 4) Pêlikê. B.F. Adolphseck, Schloss Fasanerie, 7. CVA Schloss Fasaneire (Adolphseck) 1, pl. 11. 5) Neck-amphora. B.F. (ABV 383/8) Würzburg, Max von Wagner Museum, L. 204. 6) Kylix. B.F. Copenhagen, National Museum, Chr. VIII 877. CVA Copenhagen 3, pl. 115, 3a-b. 7) Pêlikê. R.F. (ARV2 1060/135) London, E 427. Discus: Bearded piper 8) Hydria. B.F. (ABV 365/64). Capesthorne, The BromleyDavenport Collection. 9) Hydria. R.F. London, E 164. CVA British Museum 5, pl. 324.1. 10) Bell-krater. Athens, Benaki Museum, 31120. Unbearded piper 11) Olpê. Capua, Museo Campano, 155 (40). CVA Capua 2, III He, pl. 8.1-2. 12) Nolan amphora. R.F. (ARV $223 / 119)$ London, E 288. CVA British Museum 5, pl. 297.3a-b. 13) Alabastron. R.F. (ARV2 101/1) Athens, National Museum, Acropolis Collection, 866. 500-490. Javelin: Bearded piper 14) Lêkythos. B.F. Paris, Bibliothèque Nationale, H 2985. CVA Bibliothèque Nationale 2, III J a, 


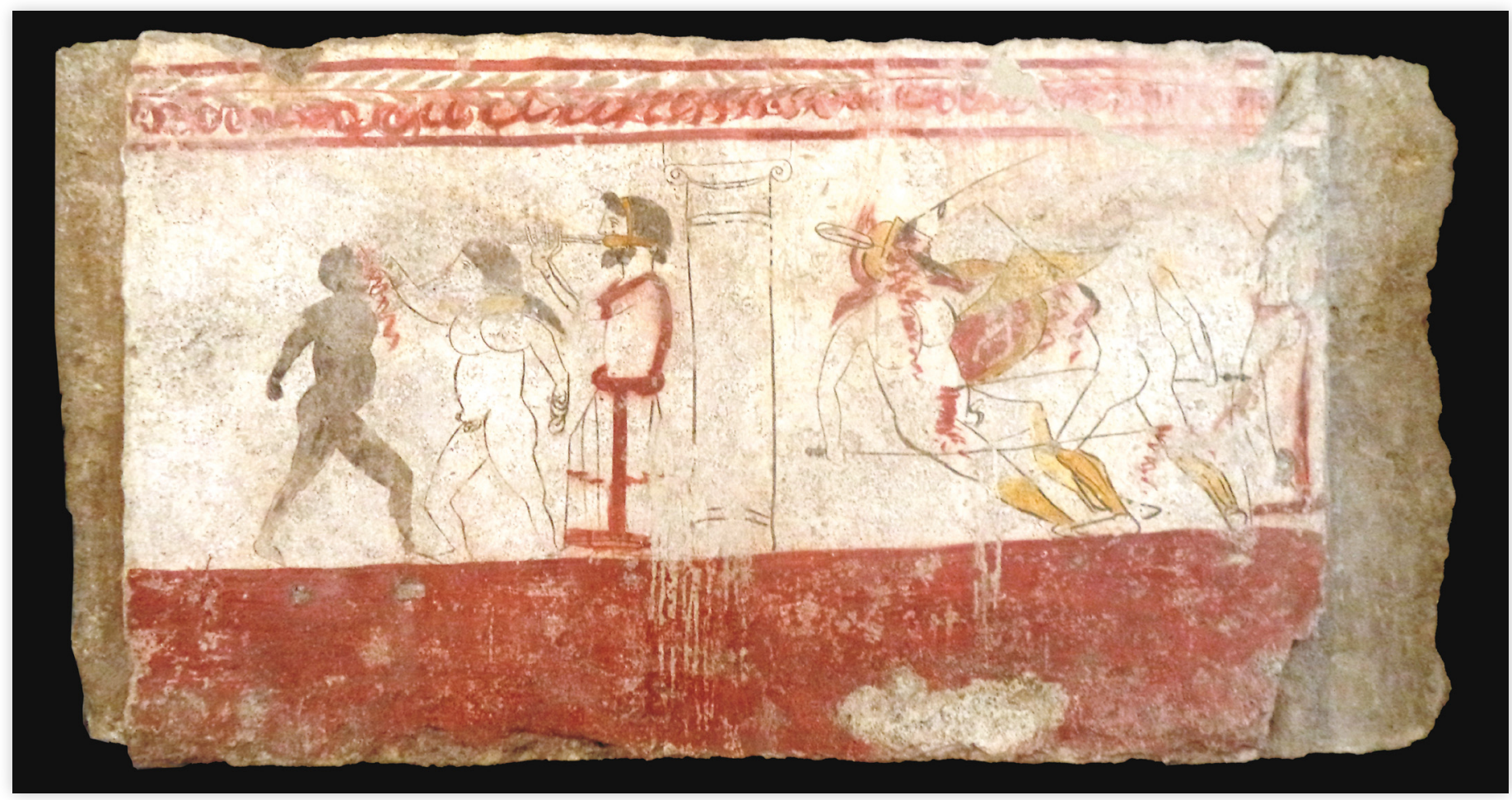

A > Figure 10

Professional aulos player, wearing phorbeia and special khiton, accompanies two boxers. Tomb painting. Paestum, Andrioulo. Tomb 24 (1971). 370-360 B.C. Paestum, Archaeological Museum. Photo: F.V. Cerqueira.

pl. 84.5-6. 15) Lêkythos. B.F. St. Petersburg, Hermitage, 149 (B 363). 16) Psyktêr. R.F. Zurich, Archäologische Sammlung der Universität, 4039. Unbearded piper 17) Amphora. B.F. Bonn, Sammlung Fontana, 44. 18) Fragment. B.F. Athens, National Museum, Acropolis Collection, 590. 19) Panathenaic amphora. B.F. (ABV 369/115) Liverpool, City Museums, 56.19.6. 20) Neck-amphora. R.F. (ARV2 272/13) Paris, G 215. CVA Louvre 6, III I c, pl. 40, 11-2. 21) Hydria. R.F. (ARV ${ }^{2}$ 16/13) Dresden, Staatliche Kunstsammlungen (Albertinum), Z.V.925. 22) Kylix (fragment). R.F. (ARV2 64/100) Amsterdam, Allard Pierson Mus., University of Amsterdam, 2229 (formerly Hague, Scheurleer Mus.). CVA Amsterdam 1, pl. 5.1, 3-4. CVA Musée Scheurleer 2, III I b, pl. 6.5. 23) Kylix. R.F. (ARV2 861/12) Berlin, Antikesammlung, 1960.2. CVA Berlin 3, pl. 105.2-4. WRESTLING: Bearded piper 24) Neck-amphora. B.F. (ABV 395/3) Munich, Antikesammlung, 1538. CVA Munich 9, pl. 7.3; 10.1-2. PUGILISM: Bearded piper 25) Hydria. B.F. (ABV 365/65) Vatican, 416. 26) Pêlikê. B.F. (ABV 384/19) New York, Metropolitan Museum of Art, 49.11.1. Running: Unbearded piper 27) Volute-krater. B.F. Athens, National Museum, Acropolis Collection, 654. Combinations of athletic modalities: Bearded piper 28) Kantharos with one handle. B.F. (ABV 345/2) Paris, Bibliothèque Nationale, 4960 (354). CVA Bibliothèque Nationale 2, III $\mathrm{H}$ e, pl. 71.1, 71.3, 71.5, 71.10. 29) Column-krater. B.F. London, B 361. 30) Lêkythos. B.F. (ABV 509/3, 703) Prague, Charles University, 20.2. CVA Prague 1, pl. 29.1-3. 31) Lêkythos. B.F. Delos, Archaeological Museum, 571 (B 6.133). 32) Kylix. R.F. (ARV2 430/31) Basle, Antikenmuseum, Kä 425. CVA Basle 2, pl. 19.2-4; 20.1-2; 36.2 e 6; 39.8. Unbearded piper 33) Lêkythos. B.F. Athens, National Museum, 12571. 34) Lekythos. B.F. (ABV 497, below) Athens market. 35) Lêkythos. B.F. Taranto, Museo Archeologico, 50287. CVA Taranto 1, pl. 15.5-6. 36) Lêkythos. B.F. Athens, National Museum, 12533. 500-490. 37) Lêkythos. B.F. Athens, National Museum, 18765. 38) Lekythos. B.F. Athens, National Museum, 12560. 500-480. 39) Calyx-krater. R.F. (ARV2 297/11) Copenhagen, Copenhagen, 126 (Chr. VIII 805). CVA Copenhagen 3, pl. 127-8. 40) Stamnos (fragments). R.F. (ARV² 15/8) Leipzig, Antikenmuseum der Karl-

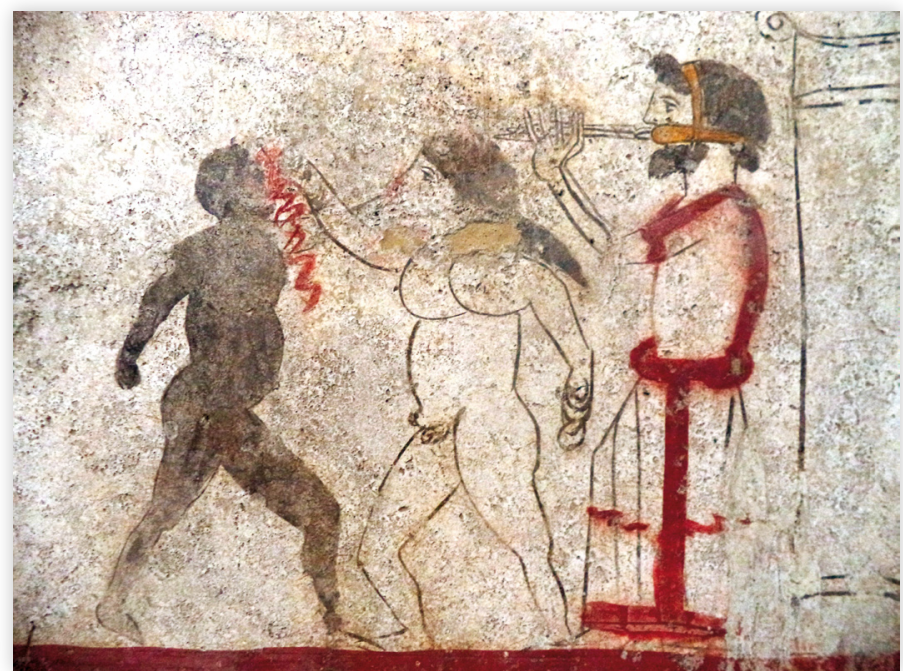

Marx Universität, T 523. 41) Psyktêr. R.F. (ARV2 54/7) New York, Metropolitan Museum of Art, 10.210.18. 525-20. 42) Kylix. R.F. (ARV2 72/15) Berlin, Antikesammlung, 2262. CVA Berlin 2, pl. 55. 43) Kylix. R.F. Malibu, J. Paul Getty Museum, 85.AE.25. 44) Kylix. R.F. (ARV2 126/23) Tarquinia, Museo Nazionale, RC 2066. CVA Tarquinia 1, III I c, pl. 6.12; 7,1. 45) Kylix. R.F. (ARV ${ }^{2}$ 150/41) Montpelier, Musée Languedocien, 137. 46) Column-krater. R.F. (ARV2 221/14) Munich, Antikesammlung, 2381. 47) Column-krater. R.F. (ARV ${ }^{2}$ 240/44) Paris, CA 1947. CVA Louvre 2, III I c, pl. 24.1-6. 48) Kylix (fragments). R.F. (ARV2 322/29) Florence, Museo Archeologico, PD 265. CVA Florence 3, III I c, pl. 92.1-4. 49) Kylix. R.F. (ARV2 351/8) Basle, Antikenmuseum, BS 438. CVA Basle 2, pl. 13.1; 14.1-2; 15.1-2. Fragments not permitting piper age identification: 50) Kratêr (fragment). R.F. Prague, Charles University, 75.5. CVA Prague 1, pl. 35.5. 51) Kylix (fragment). R.F. Paris, fr. Campana 87. CVA Louvre 19, pl. 43.2. 52) Hydria (?) (fragment). R.F. (ARV2 210/176) Athens, National Museum, Acropolis Collection, 934. 53) Neckamphora. B.F. (Para 175) Hobart, University of Tasmania, 44. 54) Kylix (fragment). R.F. (ARV2 813/95) Adria, Museo Civico, B 49. CVA Adria 1, III I c, pl. 38.7. A lost vase, known from a description: 55) Unknown form (kylix?). R.F. (ARV2 59/56) Lost (formerly Rome, Museo Torlonia, 167). 




Figure 11

Palaestra scene, with two men boxing, in presence of a judge and an aulos player. Etruscan amphora. Uprooter Class (ABV 589/3). 500-480 B.C. Berkeley, University of California, 8/445. Drawing: F.V. Cerqueira.

According to this list, the aulos accompanies the javelin in 29 cases, jumping with weights in 23, and the discus in 22 [63]. This observation reveals a trend: the painter preferred to associate the piper with javelin scenes, although it indicates a balanced interest in the main contests of the pentathlon (jumping, javelin and discus). On the one hand, this contradicts the interpretation of some modern historians [64], who, perhaps overestimating the later evidence of Pausanias, Philostratus and Themistius, supposed that the aulos-accompaniment was intended exclusively or mainly for the jumping contest; on the other hand, it corroborates the view of other scholars [65], who observed the demand for the piper in all athletic exercises. According to Plutarch, Pausanias, Philostratus and Athenaeus, the aulêtês played in the agôn at the

[63] One should observe that the painter associated the presence of the piper either to one single contest (26 vases) or to a mix of different contests of the pentathlon (23), which is why the total number of contests linked to the aulos-accompaniment is greater than the sum of the 56 vases in the inventory. This choice was determined by vase shape: scenes with a single modality prevail on amphorae and pêlikai, whose surface supported few figures, while scenes with a mix of contests prevail on kylikes and lêkythoi, whose surface supported a composition with many figures.

[64] DeCKer 1995, p. 99; LARMOUR 1999, p. 69.

[65] RASCHKE 1985, p. 178-179. GARDINER 1919, p. 302 and 476. GiRARD 1889, p. 192-193.

[66] Pseudo-Plutarch, De musica, XIV, 1136a-b.

[67] Athenaeus, XV, 629.

[68] Philostratus the Athenian, De Gymnastica, LV, 4.

[69] Ibid.

[70] Pausanias, V, 7, 10 .

[71] Ibid.

[72] Plutarch (Pseudo-Plutarch, De musica, XXVI, 1140c-d) mentions his presence in the fighting competitions in Sthenia festivals, in Argos, whereas Athenaeus (XV, 631b) refers to aulêtai accompanying dances that imitated the pankration and the fight, during the Gymnopaedia. See: LARMOUR 1999, champions' award ceremony [66], and in the pentathIon contest, during training [67] and competition [68]. Philostratus [69], in his theoretical essay on gymnastics, poses the auletic accompaniment to the jumping with weights as necessary for the "encouragement" of the jumper to accomplish what he considered the most difficult of all tests. Pausanias also refers to the performance of the aulêtês accompanying the jumping contest [70]. Nonetheless, the aulos was also employed for the accompaniment of fighting contests. Pausanias [71], in describing the decoration of the shield of Cypselos, shows athletes fighting to the sound of the aulos, which is reminiscent of scenes in the Paestan tomb paintings [72]. Understanding the reasons for the musical accompaniment with aulos of physical activities such as jumping with weights caught the attention of authors from the third and fourth centuries AD. Good examples, contemporary with the above mentioned Gallo-Roman mosaic (fig. 6) and with a Greco-Egyptian papyrus referring to the hiring of an aulos-player to accompany vintage workers, are the reflections by Flavius Philostratus (ca. A.D. 172-250), in his De arte gymnastica libellus [73], and by Themistios (A.D. 317-390), in his commentary on a passage of Aristotles, Physics 172, 26 [74]. Wolgang DECKER takes up Joachim EBERT's study concerning the Aristotelian concept of continuous and discontinuous movement, discussed by Themistius, to justify the necessity of the auletic accompaniment to jumping with weights [75].

In philosophical reflection on this movement, one confirms a relation between the performance of the aulêtês and the athlete who jumps holding the weights. Themistius states that the movement of the athlete

p. 71: "Perhaps Athenaeus interpreted the 'performances' as dances rather than athletic contests accompanied by the aulos like those at Argos".

[73] Philostratus, De Gymnastica, LV, 3.

[74] Themistius, Commentary on Aristotle, Physics, 172, 26 ss. (ed. Schenel), trans. J. Jüthner, Wiener Studien 53 (1935), $76 \mathrm{sq}$. Themistius was very close to Christian emperors of the fourth century, as Constantius II and Theodosius, being an influent intellectual.

[75] DeCKER 1995, p. 98-99. EBERT 1963. In order to understand why music improves the athletic performance, we need to retake the Aristotelian concept of "continuous" elaborated in his Physics V.3.226b (ed. Hardie \& Gaye): "That which a changing thing, if it changes continuously in a natural manner, naturally reaches before it reaches that to which it changes last, is between. Thus 'between' implies the presence of at least three things: for in a process of change it is the contrary that is 'last': and a thing is moved continuously if it leaves no gap or only the smallest possible gap in the material - not in the time (for a gap in the time does not prevent things having a 'between', while, on the other hand, there is nothing to prevent the highest note sounding immediately after the lowest) but in the material in which the motion takes place. This is manifestly true not only in local changes but in every other kind as well." 


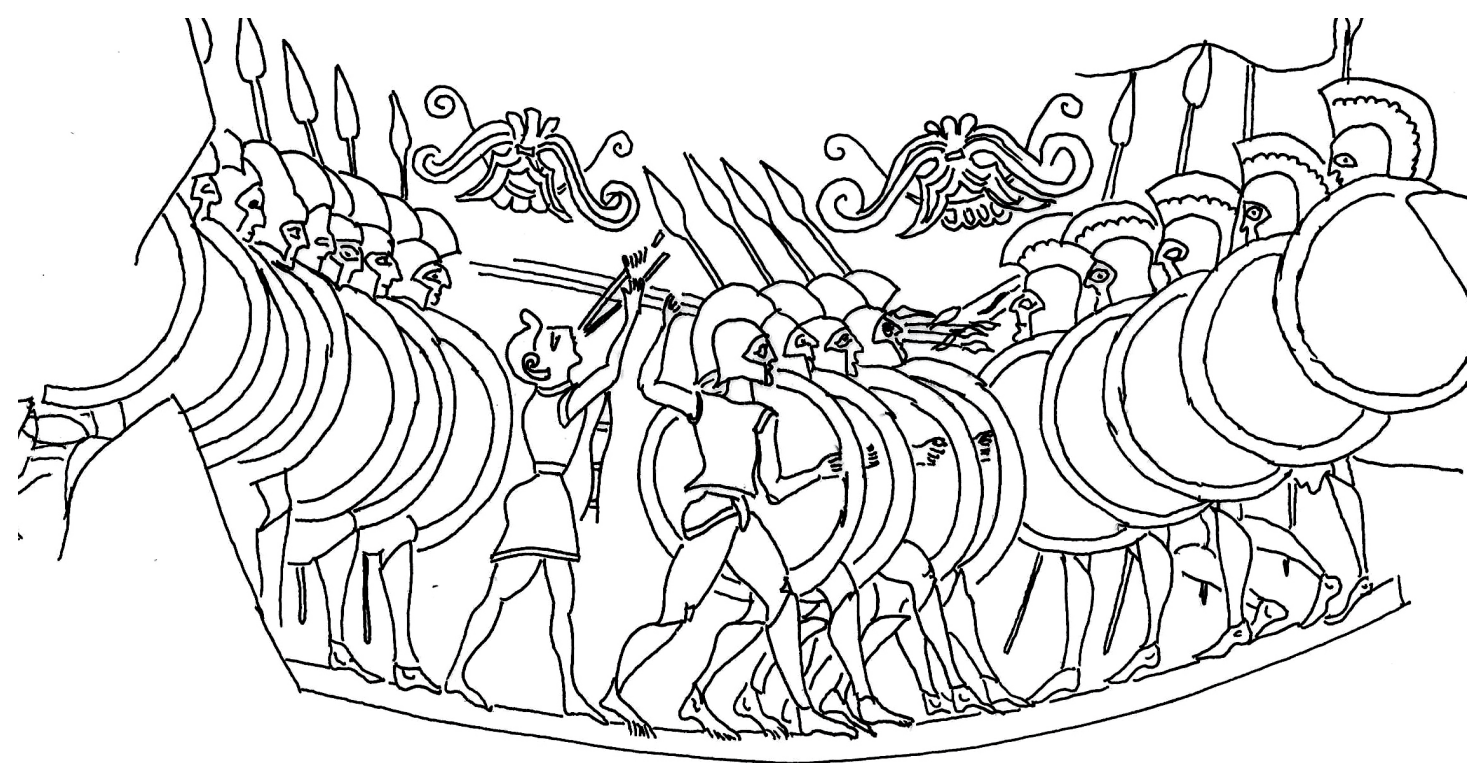

Figure 12

Aulos player accompanying hoplites. ProtoCorinthian olpe. Painter of the Chigi Olpe. c. 640-30 B.C. Roma, Museo Nazionale Etrusco di Villa Giulia, 22.679. Drawing: F.V. Cerqueira.

who accomplishes the jump in five stages is a discontinuous movement, because discontinuity is inherent to what moves, for it changes continuously; this discontinuity, for Themistius, results from the factor of time, and not of the movement itself [76]. Hence the need for music accompanying the athlete, since the musician also moves when performing - this movement, according to Joachim Ebert, is not the movement of the hands and fingers over the strings and orifices of the musical instrument, but rather in the movement of the emitted sounds [77]. The sequence of tones, regardless of the place they occupy in the scale, being rhythmically and harmonically linked, maintains a continuous sequence of movement on the part of the athlete, reducing the discontinuity inherent to his movement, which is larger when spatial displacement occurs, such as when making leaps (and therefore, interruptions). The unavoidably discontinuous movement of the athlete who accomplishes the jump in five stages approaches continuity thanks to

[76] Themistius, Commentary on Aristotle, Physics, 172, 26 ss. (ed. Schenel).

[77] EBERT 1963, p. 57, note 1: "Wir haben übrigens, was die 'Tätigkeit, in der sich der Sänger bewegt', angetrifft, wohl nicht an die Bewegung der Hand oder der Finger beim Auschlagen der Saiten zu denken, sondern an das Klingen selbst. Der Sänger bzw. Spieler bewegt sich gleichsam in Tönen. Mit

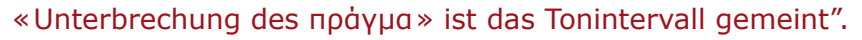

[78] Nevertheless, Assyrian reliefs show us warriors accompanied by musicians, in more remote times, what counts as an evidence of the existence of similar custom among other cultures with which Greeks held contact, even if not directly, but intermediated by other peoples. For instance, the Babylonians used to have musicians accompanying their mighty army troops. The Lydians, that influenced archaic Greece in several cultural uses, thanks to luxury and wealth, may have been the direct contact of Greeks with this traditional Oriental custom - the musical accompaniment of army - which origin goes back to distant times and lands, on the banks of the sequence of tones, which follow each other in equal tempo, regardless of the distance of the leap (interval) existing between the musical notes.

\section{THE AULOS ACCOMPANIMENT IN MILITARY LIFE}

The presence and use of musical instruments occurred at different moments. The warriors' training was mostly done to the sound of the aulos. When troops were advancing into battle, and even during military clashes, one could hear the sound of the aulos and other wind instruments, such as the trumpet (salpinx) and the horn (keras). Despite probable origins in Asia Minor and perhaps further away, in accordance with customs attested among the Lydians - and previously among the Assyrians [78] - some testimonies indicate an independent development in Greek territory, above all in Crete and Sparta. In their military expeditions, the Cretans employed

the Tigris and Euphrates. Herodotus reports that the Lydian military march was accompanied by a high-sounding orchestra of syringes, harps (pêktides), as well as acute and bass auloi (aulou gynaikeiou and aulou andreiou) (Herodotus, I, 1). According to Aulus-Gellius, besides syrinx and aulos players, the Lydians brought aulêtridai for the amusement of the warriors during their libidinous banquets (Gellius, I, 11, 7). Beyond the Lydians, probably the contacts the Greeks from Asia Minor had with Persians did also brought, to Hellenic context, ancient Mesopotamian cultural features, as the strong valorization of music, reinforcing Lydian influence. However, Herodotus anthropological view was very sagacious, since he noted the cultural difference: whilst the Greek troops had a sober musical accompaniment, usually with a single instrument, the reports regarding near-eastern uses indicate a multi-sounding accompaniment, suggesting a colorful musical atmosphere, with several instruments and timbres. Lydian troops advanced in the atmosphere of a real spectacle, suitable for the image of Oriental courts, aiming to intimidate the enemy before the image of power. 
the lyra [79], the aulos [80], or both combined [81], as well as the cithara [82]. Three of the four abovementioned refer to the use of string instruments (lyra or cithara) in Crete, thus diverging significantly from the references we have in mainland and Cycladic Greece, where the aulos and the salpinx prevail.

The hundreds of aruballoi representing warriors are evidence of the importance the Corinthian vase-painters gave to warlike matter. Concerning this theme, a masterpiece in proto-Corinthian style arouses special interest: it is an olpê depicting a young aulêtês between two hoplite phalanxes, which advance on the enemy (fig. 12). This iconographical evidence converges with the testimony of Aulus Gellius [83]. This Corinthian vase, known as "the Chigi vase", dates from the mid-seventh century B.C., C. 640 B.C., and therefore slightly after the activity of Archilochus on Thasos and contemporary with Tyrtaeus' activity in Sparta. Archilochus reports in a trimeter that Thasian troops attacked chanting a paean invoking Apollo [84], to the sound of the Lesbian aulos (pros aulon Lesbion) [85]. These verses suggest that, already in mid-seventh century, it was usual to sing a hymn to Apollo, a paean, either before the attack or after the victory, as noted by Aeschylus with reference to the battle of Salamis in the early fifth century B.C. [86] Tyrtaeus played an important role in the second Spartan katastasis ("restoration"), together with other musicians, such as Thaletas and Xenodamus. Nevertheless, Thaletas' and Xenodamus' compositions, alongside the ones of Xenocritus, Polymnestus and Sacadas, belonged to the musical repertoire of the Gymnopaedia. On the other hand, Tyrtaeus' compositions, the embatêria mele (called enoplia), a type of martial song in anapestic meter, were sung, according to Athenaeus [87], during the orderly advance of the troops, exhorting the warriors to brav-

[79] Pseudo-Plutarch, De musica, XXVI, 1140c.

[80] Polybius, IV, 20, 6-7.

[81] Strabo, $X, 4,20$.

[82] Gellius, I, 11, 6.

[83] Gellius, I, 11, 3. The passage is analyzed further below. [84] Archilochus, fr. 110, vs. 10-15 (ed. Lasserre \& Bonnard), Inscr. Sósthenes IV, 54, 5. It must be the same Lesbian paean referred to in a tetrameter, which indicates that it has to be sung in the moment of attacking.

[85] Archilochus, fr. 88 (ed. Lasserre \& Bonnard), ap. Athenaeus V, 180d-e. Lesbos had, in Antiquity, an important reputation thanks to famous musicians. Terpander was the first among them, according to the evidence of ancient texts. Terpander and Archilochus, though not having the same age, have been contemporary in some moment in their lives; however, ancient texts are not according about who was older. The reputation of Lesbos is mainly connected with stringed instruments (Terpander and Arion, Sappho and Alcaeus, and, why not, the tale about the lyra and the head of Orpheus). Nonetheless, the chronic of the Marble of Paros refers to Terpander of Lesbos as an aulêtês - so helping us to ery [88]. That was how he contributed to the Spartan victory in the twentieth year of the Second Messenian War (c. 668 - c. 600 B.C.) [89].

Mythological narratives attribute the introduction of the martial song called Kastoreion in Lacedaemon to Castor and Pollux. The song's early origin established it deeply in social memory, merging it with the mythical origins of Sparta and creating the perception of autochthony. Starting from this repertoire, the Spartans developed armed dances, accompanied by the aulos. According to Athenaeus, the dance of war, the so-called purrhichê, a traditional component of Spartan festivities and education, performed by boys in arms, functioned as training for the body, preparing it for the speed and agility required by war, in attacking and escaping [90]. According to Lucian of Samosata [91], Castor and Pollux taught the Spartans the Carvatic, a sort of dance in arms. For Plutarch [92], Lycurgus, who was contemporary with or somewhat later than Tyrtaeus, linked the music to the agôgê, the Spartan military education system. Plato testifies how far music was closely bound to military formation in Sparta, reporting that Spartan children were saturated with the music of Tyrtaeus at school [93].

One of the musical genres likely used in the accompaniment of the military marches was the nomos, like the Nomos of Ares, composed in enoplic meter, which would have been played during combat [94]. The warlike nomoi and enoplic songs were accompanied by the aulos. However, the salpinx (trumpet), poor in terms of melody and without connection to song, was frequently used as an accompaniment to military activities. Plutarch testifies to the differences in the military traditions: while the Lacedaemonians preferred to march into combat to the sound of the aulos, other peoples did so accompanied by the salpinx [95]. The Greeks from Asia Minor associated

understand the expression pros aulon Lesbion.

[86] Aeschylus, Persians, 393.

[87] Athenaeus, XIV, 630f.

[88] Dion Chrisostomus, II, 59. CoRreA 1987, p. 95.

[89] Suda, Tyrtaeus 1. Tyrtaeus flourished in the $35^{\text {th }}$ Olympic Games (640-37 a.C.), when he settled in Sparta to contribute to pacify the people, by means of his music, by overcoming the rivalries arising from social crisis. He composed martial songs in anapaestic meter and also elegies, which induced people, at same time, to peace and political order, to excellence and bravery.

[90] Athenaeus, XV, 630. The aulos kept the rhythm of the purrhichê, for it accompanied all dances marked by quick movements.

[91] Lucian, De saltatione, 10.

[92] Plutarch, Instituta lacônica, c.16.

[93] Plato, Laws, 629a.

[94] Pseudo-Plutarch, De musica, XXIX, 1141b. Cfr. XVII, $1137 a$.

[95] Pseudo-Plutarch, De musica, XXVI, 1140c. 
the aulos with war. Some Clazomenian sarcophagi, dated from the first half of the fifth century B.C., represent an aulêtês accompanying figures dressed like hoplites [96]. In the second century B.C., when many Greek regions had already abandoned traditional usages, in Arcadia, according to Polybius, a rigorous musical and military education was preserved: young boys marched to the sound of the pipes in order to maintain good order [97].

Concerning Sparta, there is a large number of testimonies. These report, almost in unison, that the aulos was the musical instrument used to support military activities among the citizens, accompanying both training and combat [98]. Even Tyrtaeus is remembered in this tradition as an aulêtês [99]. Thus it was with the aulos that they played the so-called Kastoreion every time they advanced against the enemy. Nevertheless, other instruments were incorporated into the musical accompaniment during the Hellenistic and Imperial periods, as deduced from Pausanias [100], who reports that the Spartans marched to the music of the aulos, accompanied by the lyra and the kithara. In the same vein, Sextus Empiricus mentions the aulos and the lyra [101]. Abandoning traditional Spartan austerity, the change in military customs corresponds to a new taste for exuberant spectacles common to the Imperial period, causing a change in the role of musical accompaniment: for the Spartans in Archaic and Classical period, it was not a spectacle, but rather an absolute requirement of phalanx discipline.

On the other hand, there are abundant testimonies of the use of the trumpet in the military environment.

[96] The set of Clazomenian terracotta sarcophagi corresponds to approximately 120 exemplars. In a well-known sarcophagus attributed to the Albertinum Painter, conserved in British Museum, dated from around 500/490 B.C., one sees a naked aulêtês playing between two hoplites. On the debate between A.S. Murray and R.M. Cook about the identification of the scene, if a real fight (Cook) or a purrhichê in funerary games (Murray), see Cfr. Corpus Vasorum Antiquorum, British Museum 8, text, p. 50).

[97] Polybius, IV, 20, 12.

[98] Thucydides, V, 70; Polybius, IV, 20, 6-7; Pseudo-Plutarch, De musica, 1140c; Instituta laconica, c.16; Lucian, De saltatione, 10; Gellius, I, 11, 1-4 e 10.

[99] Suda, Tyrtaeus.

[100] Pausanias, III, 17, 5.

[101] Sextus Empiricus, Agains Musicians, XVIII. Alcman speaks of war accompanied by kaloos kitharisden, translated by Campbel as "(...) fine lyre-playing tips the scales" (Alcman, fr. 41 [ed. Campbel], ap. Plutarch, Lycurgus, XXI, 6). It should be noted that such alternative versions to the aulos in the musical accompaniment to military activities date from the Imperial period, since the fragment attributed to Alcman is not known to us from any source before Plutarch.

[102] Polybius, IV, 20, 6-7.

[103] Philostratus. De Gymnastica, VII, 18-19.

[104] Amazons blowing salpinx: 1) Epinetron (fragments) b.f. Eleusis, Archaeological Museum, 907. 2) Lêkythos, b.f.
Attention is required in order to understand what is particular to each instrument in military context. Pausanias and Polybius point out that Spartans and Cretans did not use the salpinx: according to Polybius, they preferred the aulos and rhythm [102]. In emphasizing the fact that the Spartans and Cretans were unusual in not using the salpinx, their testimony constitutes evidence that the salpinx was standard in warlike contexts. Philostratus was of the opinion that the point of employing the salpinx was to "incite" the warriors to arms - it was a galvanizing technique [103]. Athenian authors from the classical period, such as Aeschylus, Thucydides and Xenophon, attest to the varied functions of the trumpet in war, suggesting that this was the musical instrument used in military contexts in Athens as well as in many other regions, and that it was used in different moments of the battles. The Attic iconographical testimonies from late archaic and classical periods, in black- and red-figures, represent the salpinx as the main military musical instrument, by means of mythological representations featuring Amazons [104] and Ethiopians [105], and representations of hoplites (fig. 13) [106]. The Athenians employed the trumpet to give the signal to attack [107], as well as to escape [108]. Such usage was common among other Greek and barbarian peoples [109]. Aristides Quintilianus provides the most detailed description of the different orders given by the salpinx, explaining that its orders are safer than those expressed by words, for oral orders can be misunderstood by soldiers and understood by enemies [110].

Athens, National Museum, 12738. 3) Lêkythos, b.f. Athens, National Museum,12782. 4) Oinochoê, b.f. Ferrara, Museo Archeologico, T 915. 5) Kylix, r.f. (ARV² 62/77) Oxford, Ashmolean Museum, 1927.4065. 6) Kylix, b.f. (ARV² 43/74; 55/15) Vatican, Museo Gregoriano, 498. 7) Kratêr, r.f. London, F 158 .

[105] Ethiopians blowing salpinx: 1) Amphora, r.f., Würzburg, Martin von Wagner Museum, L 508. 2) Amphora, r.f., Vienna, Kunsthistorisches Museum, IV 3724.

[106] Hoplites blowing salpinx: 1) [Fig. 13] Plate, b.f. (ABV 294/19) London, B 590. 2) Plate, b.f. (ABV 294/20) London, B 591. 3) Kylix, r.f. (ARV² 1628 , ad. A $135 / 9$ bis) Geneva, Musée d'Art et d'Histoire, 20.152.1964. 4) Kylix, r.f. (ARV² 402/17) Brussels, Musée du Cinquantenaire, R 322. 5) Kylix (fragment), r.f. Tarquinia, Museo Archeologico, 72/20048.

[107] Aeschylus, Persians, 392-395; Thucydides, VI, 69, 2.

[108] Thucydides , V, 10, 3.

[109] In attack: Xenophon, Hellenica, V, 1, 9. In the satrapa's escape: Xenophon, Anabasis, IV, 4, 22.

[110] Aristides Quintilianus, p. 62, 11-20 e 72, 12. BÉLIS 1984, p. 99-100. The Greek technique of musical training of horses was employed in the commands and synchronized maneuvers of the cavalry, under different signs of the salpinx, as we learn from the detailed description in Xenophon, On the Art of Horsemanship, III, 11-1, portraying the spectacle of military discipline of the cavalry, thanks to the animals' training and to the comprehension of the trumpetist's orders by the horsemen. 


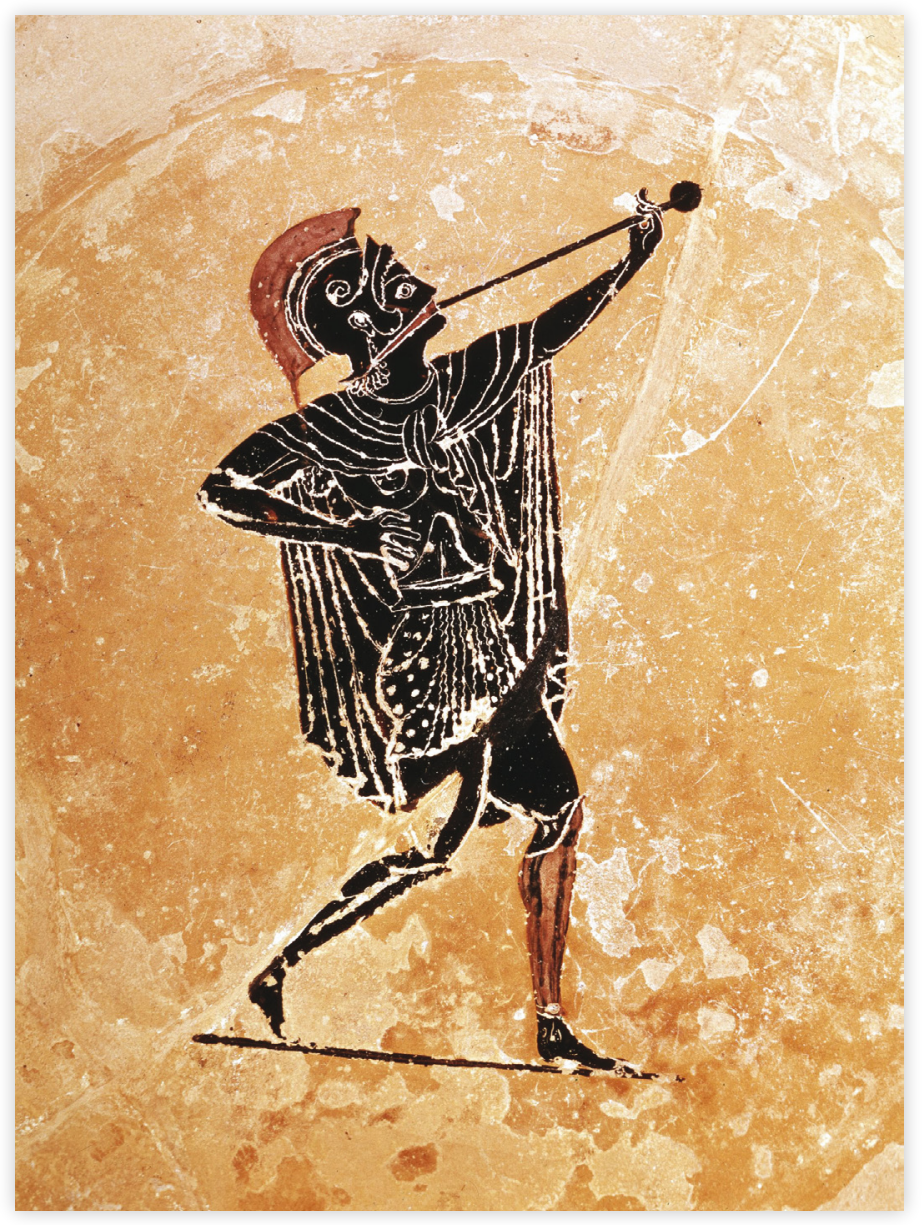

Figure 13

Warrior wearing khitoniskos and helmet, moving to right, plays a salpinx (trumpet), using phorbeia. Attic black-figure plate. Psiax (ABV 294/19). 520-15 B.C. London, British

Museum, B 590. (C) Trustees of the British Museum.

What would be the difference between using the pipes or the trumpet in the accompaniment of warlike activities? In a military context, the communicative and tactical use of the salpinx, which was in addition deprived of both melos and logos (understood as a text), differs from the purpose of aulos songs, the military function of which was linked to rhythm and discipline. The written sources are very clear in attributing a sophisticated sense of the use of music to the Spartans, explaining how far it contributed to the success of their troops. As Sextus Empiricus reveals, they believed "that music commanded them always in the battles" [111]. Lucian states that they became almost undefeatable, because they were led by the aulos and the rhythm [112]. Thucydides, a keen observer of military issues, comments on how the auletic accompaniment helped the Spartan army to obtain good results [113]. In short, he argues that the main difference in the Spartans' uses of the aulos was that with its music they ensured the unity of the phalanxes, for they "march up with even step and without breaking their order". Other armies, not using the aulos, failed to keep the order established in training. Half a millennium later,
Aulus Gellius, regarding the same Thucydidean passage, provided a more complex anthropological explanation:

Thucydides, the most authoritative of Greek historians, tells us that the Lacedaemonians, greatest of warriors, made use in battle, not of signals by horns or trumpets, but of the music of pipes, certainly not in conformity with any religious usage or from any ceremonial reason, nor yet that their courage might be roused and stimulated, which is the purpose of horns and trumpets; but on the contrary that they might be calmer and advance in better order, because the effect of the flute-player's notes is to restrain impetuosity. So firmly were they convinced that in meeting the enemy and beginning battle nothing contributed more to valour and confidence than to be soothed by gentler sounds and keep their feelings under control. Accordingly, when the army was drawn up, and began to advance in battle-array against the foe, pipers stationed in the ranks began to play. Thereupon, by this quiet, pleasant, and even solemn prelude the fierce impetuosity of the soldiers was checked, in conformity with a kind of discipline of military music, so to speak, so that they might not rush forth in straggling disorder [114].

Thus the military function of the salpinx was firstly strategic communication of orders and signs, and secondly to stimulate and encourage. On the other hand, the function of aulos music, at a more immediate level, was rhythmical, for the rhythm ensures moderation and measure, guaranteeing that the warriors would preserve the strategic formation of the hoplite phalanx, which was composed of soldiers who were parts of a coherent whole. Nevertheless, the function of the aulos was not limited to its rhythm, since its melodic dimension also played an important role. The melody, carrying the musical sweetness praised by the poets' verses [115], contributed to military discipline as well, for it prevented the excessive and individualistic enthusiasm of the warrior, and reduced his thirst for violence. The success of the army depended on the sense of measure [116], ensuring that each warrior, disciplined and soothed by the order of rhythm and by the sweetness of the melody of the aulos, succeeded in remaining engaged in the established order.

[111] Sextus Empiricus, Against Musicians, 8.

[112] Lucian, De saltatione, 10.

[113] Thucydides, V, 70.

[114] Gellius, I, 11, 1-4 (ed. John C. Rolfe).

[115] Pausanias, IX, 23.

[116] On the relation between the hoplitic revolution and the sense of collectivity, that supposedly succeeded the Homeric aristocratic military individualism, see: VERNANT 1964. 
However, its enemies, who did not submit their armies to the disciplining power of music, saw their troops fall into disarray at the very moment when they had to begin combat.

\section{FINAL REFLECTIONS}

Returning to the question regarding the internal logic behind the musical accompaniment of physical activity, it seems relevant to observe the scenario depicted by an Egyptian contract of employment from fourth century $A D$, recorded on a preserved papyrus [117]. In $A D$ 322, a farmer of Hermopolis [118], a Greek community of Egypt, hired an auletes, called Psenumis, to play during the vintage, in order to support the peasants' work through his music. At first glance, the situation may seem anecdotal, but let us try to understand the reason why the farmer decided to hire a musician. Hiring a musician to work in an economical activity surely obeys an economical logic. The piper's performance was necessary for the development of the workers' routine - the farmer did not employ the musician out of generosity to his workers, but for the productivity of his vineyard. The strength of this economic logic helps us to comprehend the resilience of such usage, as supported by the iconographical evidence in mosaics of Late Antiquity [119]. From the Würzburg krater by the Amasis Painter from the sixth century B.C. (fig. 2), up to the Gallo-Roman mosaic from the third century $A D$ (fig. 6) and later exemplars from Israel, Jordan and Lebanon from the sixth century AD (fig. 3), passing through the fourth century AD Egyptian contract, we may observe a form of social and economic continuity.

Therefore, our interpretation should take advantage of the concept of "longue durée", that provides the historian with a different treatment of temporality, permitting the establishment of an anthropological synchrony among diachronic historical testimonies, enabling one to put into dialogue, for mutual comprehension, situations verified in different periods and regions during Antiquity. What could be viewed by modern eyes as merely pictur-

[117] Select Papyri: Vol. 1: Non Literary Papyri Private Affairs - Private Documents, transl. and ed. by A.S. Hunt \& C.C. Edgar, London (Loeb Classical Library), 1932, n. 22. BÉLIS 1999 , p. 71.

[118] Called Eugenios, he was gymnasiarch and senator.

[119] It is worth remembering that this agrarian musical custom reverberated until the $20^{\text {th }}$ century, by means of a resilient cultural tradition. For instance in Lebanon, according to ethnographic reports regarding the 1930s, one witnessed the use of a kind of double flute during the olive harvest, in order to prevent the peasants to sleep. See: Feghali 1935, p. 167. esque in fact makes sense as a cultural institution, rooted in musical and agrarian culture, which had a long life in a number of rural activities in the ancient Mediterranean.

We anticipate our conclusion. The musical accompaniment by the aulos in wine production, as well as in sport and war, is dependent on the music's utility, but what is this utility? It serves the rhythmic demands required by physical activities that involve repetitive movements, contributing also to reinvigorate the spirit of those who must perform these strenuous tasks [120], a function in which both the melos and the logos can play a role. According to ancient thought, music should be considered as the combined effect of rhythmos, melos (the melodic, harmonic aspects of the song) and logos (the discursive aspect of the song, the sung words, or the poem that one sings) [121]. However, these have different effects. The Aristotelian author of Problems XIX.25 argues that it is more important to imitate feelings through the melos than through the logos, though in modern times we might suppose the opposite, i.e. that words would be more effective in imitating emotion than a melody. The effect of the ethos was namely present in rhythm, though also in melody, since rhythm and melody are both movements, as well as actions [122]. Furthermore, this essentially rhythmical and melodic ethic aspect is linked to the quality of continuity, since sound is transmitted through the continuously moving air [123]. This continuity was linked to aulos music, because the sound of the aulos, as a wind instrument, is a product of moving air.

From the standpoint of the anthropology of music, a situation repeats itself for around a millennium during Antiquity. This repetition calls attention. Let us reflect a little bit more on the utility of employing the aulos. It was useful because it was necessary, but in what did this necessity consist? The answer is most likely identical in the case of the auletic melodies (called aulêma) present in the various work activities that we have mentioned. When treading grapes, milling grain and kneading dough, there is a need for synchrony and regularity in repeated movements. Fundamentally, the same regularity required by the movements of athletes, warriors aligned in phalanxes and rowers [124]. The song

[120] According to the Aristotelian author of Problems XIX.1, thanks to the music of aulos, those who suffer, suffer less.

[121] Aristotle, Problems, XIX.

[122] Aristotle, Problems, XIX, 27; XIX, 29. On the other hand, colours and flavours do not have ethic character, for they are not movement.

[123] Aristotle, Problems, XI, 6.

[124] In the three last mentioned activities, it was usual to have the presence of salpinx players, although for different reasons. 
performed by the piper in such collective labour activities helped the workers to sing together [125], and to preserve the rhythm that was necessary to accomplish the goal of their tasks.

In all these activities, whether labour, athletic or military, the aulos accompaniment, while helping to maintain synchronized and steady rhythm, simultaneously stimulates the spirit to endure the effort and exhaustion that results from the repetitive and strenuous nature of these activities - effects that could negatively affect productivity. In this sense, the melody was considered a comfort to the spirit, enabling a certain calm and allowing entertainment during hard work. It is worth noting that this second factor (the melodic factor), while inseparable from the first one (the rhythmic factor), has not yet received proper attention in modern studies, despite being clearly expressed in the sources.

But, after all, why use the aulêma and the aulos, instead of percussion or string instruments? The Aristotelian author of Problem XIX.43, although reflecting on theatrical performances, provides a clue regarding the reason for choosing the aulos as the accompaniment of physical activities. He argues that the sounds emitted by the aulos and by the voice were akin to each other, for both are produced by blowing. On the other hand, the sounds of the lyra are "thin" by nature, in so far as they do not merge well with the voice [126]. From this explanation, based on the physis of the sound, it is possible to infer that the lyra would produce a "broken", discontinuous and interrupted sound, while the sound of the aulos, by blowing, would be more continuous. The continuity of the sound of the aulos was considered necessary to guarantee its function of regulating the rhythm of movement, not only because it reduces the discontinuity inherent to movement [127] as an effect of the continuity of the blown sound, but also as result of an acoustic effect. For the sound of the lyra, more timid and discontinuous, loses much of its effect under the noise produced during a number of relevant physical activities [128].

As we have pointed above on the analysis of Themistius on Aristotle 172.26ss and Aristotle Physics V.3.226b, the

[125] Aristotelian authors of Problems XIX.22 and XIX.45 learn us that many people singing together preserve the rhythm.

[126] The sounds emitted by the lyra produced in the listener the particular impression that each of them existed on their own, insomuch that any singer's error would be perceived.

[127] Aristotle, Physics, V, 3, 226b.

[128] Apart from that, acoustically, the aulos performed better than the lyra in outdoor spaces where working songs were played, either the arias that incited the athletes to endures the physical effort in the palaestrae or gymnasia, or the songs executed in the noisy deck of a trireme. singer or the instrument player, as well as the athlete in jumping, could find continuity of movement in the sound, because it provides the tempo - and it is the time, for Aristotle, that counts most in the definition of continuous movement. Hence, music was a way to make the movement of the athlete almost continuous, for it reduced to a minimum the perception of leaps and interruptions that make movement discontinuous. It seems reasonable to add to this argument the Aristotelian concept exposed in Problems XIX.43, analyzed above, that the sound of the aulos has the capacity to produce the sensation of continuity of sound. For us, this reasoning contributes to an understanding of the cultural logic underlying the enduring permanence of the custom of accompanying physical activities with aulos songs.

Perhaps these reasons influenced Aristotle to consider the aulos an instrument that "incites to action" [129]. Concerning songs that accompanied the athletic contests or the so-called 'working songs', the function of encouraging physical effort [130], which is a function stimulated by the rhythm, merges inseparably with the function of relieving fatigue, which is afforded by the melos. The melody sung by workers, as in the vintage, milling or rowing, brings joy and softens the arduous and painful movement resulting from strenuous and repetitive activities [131]. Aristides Quintilianus demonstrated his consciousness of the inseparable rhythmic and melodic functions of music, in considering music as a gift that helped to endure fatigue, encouraging handymen to withstand strenuous efforts when coordinated by pleasant and amusing songs [132].

To battle fatigue, to encourage physical effort, to regulate and to provide rhythm for repetitive and tiresome physical movements, based on regularity and necessary continuity - music played all these roles in the accompaniment of athletic contests, military actions and working tasks. All these actions are based on repetitive movements that require rhythmic planning. According to Sextus Empiricus, the aulos assisted the accomplishment of any work that needed "well-marked tempo, with the purpose of ordering thought" [133].

[129] Aristotle, Politics, VIII, 6, 1341a. BéLIs 1999, p. 76.

[130] Athenaeus, XIV, 629c.

[131] BÉLIS 1999, p. 75.

[132] Quintilianus, Instutio oratoria, I, 10, 16 (ed. Butler): "Indeed nature itself seems to have given music as a boon to men to lighten the strain of labour: even the rower in the galleys is cheered to effort by song. Nor is this function of music confined to cases where the efforts of a number are given union by the sound of some sweet voice that sets the tune, but even solitary workers find solace at their toil in artless song."

[133] Sextus Empiricus, Against Musicians, XVIII. 
Nevertheless, power was attributed to aulos music thanks to its melodic effect, which had a pacifying virtue. For instance, according to Plutarch, the Thebans introduced the aulos in both serious moments and amusement, in order to calm and sweeten the impetuosity and hard character of their citizens, attributing honor and distinction to the aulos-performance [134]. The same virtue was attributed to the effect of the aulos music of Thaletas of Crete and Tyrtaeus. These musicians took part in the second Spartan katastasis, in which the aulos played an important role, accomplishing a pacifying function, harmonizing the opposite sides, and thus simultaneously playing a political role thanks to its melodic qualities [135]. To "restrain the impetuosity" [136] of the warriors, as argued by Aulus Gellius, or to "lighten the strain of labor" [137]. as asserted by Aristides Quintilianus, or to cause less grief to those who suffer, as defended by the author of the Aristotelian Problem XIX.1, all are qualities of the aulos resulting from its melos, and not from rhythmos. Thanks to the pleasant and amusing songs, labourers were encouraged to withstand strenuous efforts, because "even the rower in the galleys is cheered to effort by song" [138] and the peasant's work during the vintage was supported by the aulos-player [139].

Considering the previous questions about the underlying logic of the musical accompaniment of different physical activities, we conclude that there were two different levels of impregnation of the internal logic. The melos and the rhythmos were linked with a trans-historical character, while the logos was mainly related with a particular level, that belonged to the singularity of each event and phenomenon. For example, the rhythm and melody were responsible for many of the virtues, as

[134] Plutarch, Pelopidas, XIX, 1. RoesCH 1995, p. 126, nota 5. [135] Gostoli 1988, p. 231-237. Sources are not univoque regarding neither the real name of the musician, Thaletas or Thales, nor his instrument, the lyra or the aulos; however, concerning his origin, sources are in accordance: Gortyna, in Crete. According to Plutarch, de Musica, X.1134d, his name would have been Thaletas and his instrument the aulos; on the other hand, in Plutarch Lycurgus 4, his name is Thales and his instrument the lyra; for Pausanias I.14.4, his name was Thales, but the instrument is not cited. According to Plutarch, Thaletas developed his rhythms based on the aulos music originally created by the legendary musician Olympus, known for his sweet, charming melodies. Later on, other pipers, such encouragement and discipline, so that it was usual to have the musical accompaniment of work, sport and military activities. The poetic discourse of the musical logos was linked more with particular events or with singular cultural traditions. During the pentathlon, it was usual to play the Puthikon aulêma, borrowed from the Delphic Games. Though having an agonistic feature, suitable for games, the most important reason, since the accompaniment in sport was only instrumental, could be the musical tradition of this aulêma as a musical genre specially known for the spectacle of the professional virtuosity of aulos-players as Sacadas of Argos.

On the other hand, in some cases the logos was related to the cultural meaning of the situation. The discursive meaning of the songs performed in work activities, for example the epilênion aulêma ("presser song"), as suggests the title, should be directly linked with the wineproduction. In some cases, however, it was arbitrary, with no relation regarding the semantics of the sung poems. This was the case of the alêtis [141], performed as a "vintage song", but originally linked to the Aiora in honor of Erigone. But why this connection? Just because this party was celebrated in Athens simultaneously with the vintage period.

Thus, this study reveals that concerning rhythmos and melos there is an internal logic, common to many physical activities along a large period in Antiquity. To synchronize movements, for example leg movements in grape-pressing or hand movements in bread-kneading, to insert them into a common tempo, into a tempo controlled like the pulse of a metronome, and at the same time to make movement repetition less monotonous - these functions, within this cultural system, were all carried out by the aulos.

as Polymnestus of Colophon and Sacadas of Argos, played a similar role, contributing to the reestablishment of the social and political order in Sparta with their aulos performance (Pseudo-Plutarch, de Musica, IX, 113b-c).

[136] Gellius, I, 11, 3 (ed. John C. Rolfe).

[137] Quintilianus, Instutio oratoria, I, 10, 16 (ed. Butler).

[138] Ibid.

[139] Select Papyri, n. 22 (ed. A.S. Hunt \& C.C. Edgar).

[140] Philostratus the Athenian, De Gymnastica, LV, 4.

[141] Athenaeus, XIV, 618e. Cfr. Pollux, IV, 55. 
BARKer, Andrew, 1989, Greek Musical Writings I. The Musician and his Art. Cambridge Readings in the Literature of Music, Cambridge.

Bélis, Annie, 1984, "Un nouveau document musical", Bulletin de Correspondance Hellénique 108, 1, p. 99-109.

BélIs, Annie, 1989, "Les instruments de la Grèce Antique. Des vestiges à la reconstituition", Les Dossiers d'Archéologie 142, p. 41-47.

BéLIS, Annie, 1998, "Les fabricants d'auloi en Grèce: I'exemple de Délos", Topoi 8, p. 777-790.

Bélis, Annie, 1999, Les musiciens dans l'Antiquité, Paris.

Correa, Paula da Cunha, 2003, Harmonia: mito e música na Grécia Antiga, São Paulo.

DeCKer, Wolfgang, 1995, Sport in der griechischen Antike. Vom minoischen Wettkampf zu den Olympischen Spielen, München.

DéonNA, Waldemar, 1938, Le mobilier délien, Exploration Archéologique de Délos, fasc. 18, Paris.

EberT, Joachim, 1963, Zum Pentathlon. Untersuchungen über das System der Siegerermittlung und der Ausführung des Halterensprunges, Berlin.

ECKERSLeY, Tracey Elizabeth, 1995, Iconography of the vintage in the mosaics of Roman Spain and North Africa, Master of Arts thesis, Hamilton, Ontario.

Feghali, Michel, 1935, Contes, légendes, coutumes populaires du Liban et de Syrie, Paris.

Gardiner, Norman, 1919, Greek Athletic Sports and Festivals, London.

Girard, Paul, 1889, L'éducation athénienne au Vème et au IVème siècle av. J.-C., Paris.

Gostoli, Antonietta, 1988, "Terpandro e la funzione etico-politica della musica nella cultura spartana del VII sec. a.C.", in Bruno Gentili e Ricardo Pretagostini (ed.), La musica in Grecia, Roma - Bari, p. 231-237.

Graham, A. J., 1992, "Thucydides 7.13.2 and the Crews of Athenian Triremes", Transactions and Proceedings of the American Philological Association 122, p. 257-270.

LaIng, Jr. \& Donald, R., 1965, A new interpretation of the Athenian Naval Catalogue, IG 112 1951, Diss., Cincinnati.

LAMBin, Gérard, 1992, La chanson grecque dans l'Antiquité, Paris.

LARmour, David H. J., 1999, Stage and Stadium. Drama and Athletics in Ancient Greece, Hildesheim.

Pontrandolfo, Angela, Rouveret, Agnès \& Cipriani, Marina, 1997, Les tombes peintes de Paestum, Paestum.

RAschKe, W. J., 1985, "Aulós und Athlete. The Function of the Flute Player in Greek Athletics", Arete 2, 2, p. 177-200.

Rocconi, Eleonora, 2010, "Tradizioni musicali popolari nelle comedie di Aristofane", in Maria Silvana Celentano (ed.), Riccerche di metrica e musica greca per Roberto Pretagostini, Allessandria, p. 25-44.

Roesch, Paul, 1995, "Famiglie di auleti in Beozia", in Donatella Restani (ed.), Musica e mito nella Grecia antica, Bologna.

Sbardella, Livio, 2009, "Erga Charienta: Il cantore e l'artigiano nello scudo di Achille", Annali dell'Istituto Universitario Orientale di Napoli, Sezione Filologica 31, p. 65-66.

VANDensteendam, Ghislaine, 1988, "Regards sur la musique de la préhistoire à la protohistoire celtique", Bulletin Préhistoire du Sud-Ouest, Nouvelles Études 5, 2, p. 123-130.

Vergara Cerqueira, Fábio, 2004, "Esporte e música na Grécia antiga. Abordagem baseada na interface entre a iconografia dos vasos áticos e os textos antigos", Classica. Brazilian Review of Classical Studies 17-18, p. 165-183.

Vernant, Jean-Pierre, 1964, Les origines de la pensée grecque, Paris.

VeYne, Paul, 1976, L'inventaire des différences, Paris. 